البحوث

واللدراســـات 


\section{شركة مساهمة|لبحيرة}

\section{ونشاطها الزراعى والصناعىفى مصر \\ وخارجها (1AMO - IAM )}

$$
\begin{aligned}
& \text { د. عبد الرحمن محمد البكرى أبو الحمايل } \\
& \text { مدرس التاريخ الحديث والمعاصر } \\
& \text { كلية الآداب - جامعة دمياط }
\end{aligned}
$$




\section{شركة مساهمة البحيرة ونشاطها الزراعى والصناعى}

\section{فى مصروخارجها (1911 - I9V0)}

د/ عبدالرحمن محمد البكرى أبو الحمايل

اتجهت الأموال الأجنبية إلى الأرض الزراعية، التى ترجع صلة الأجانب بها

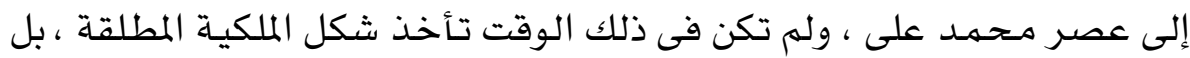

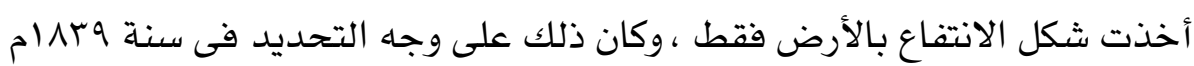

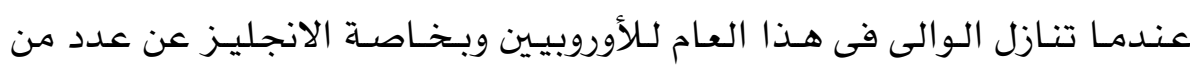

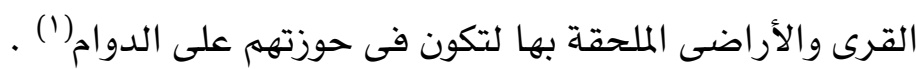
كذلك منح محمد على بعض الأجانب أطياناً من الأبعاديات صارت لهم ملكاً

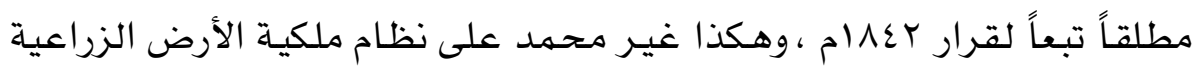

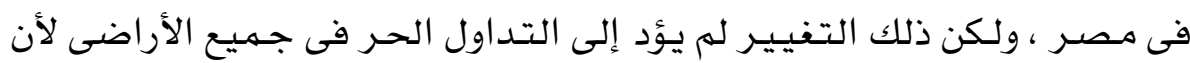

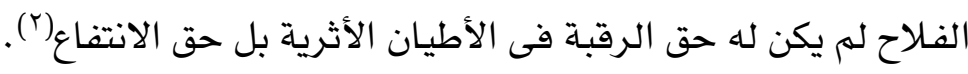

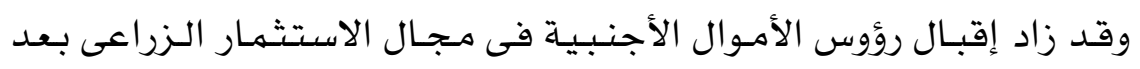

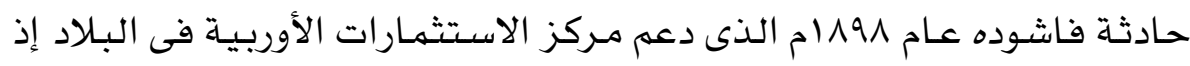

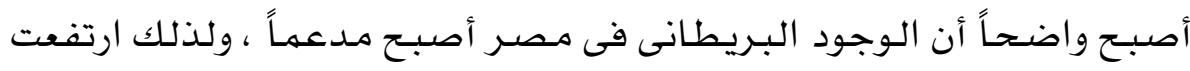

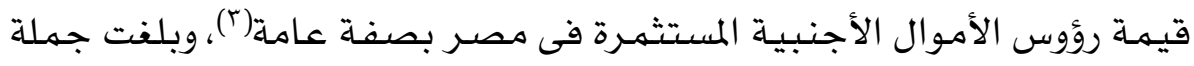

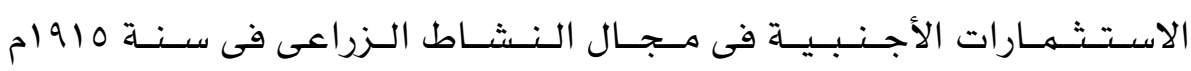

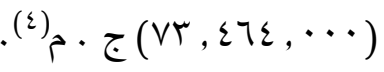

ولذلك تتفرد الاستثمارات الأجنبية فى مصر بطابع يميزهـا إلى حد ما عن

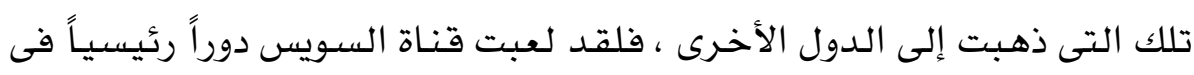

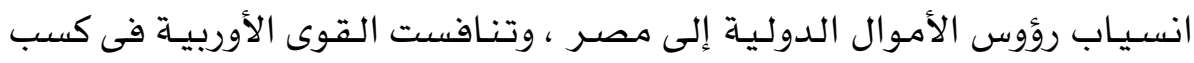

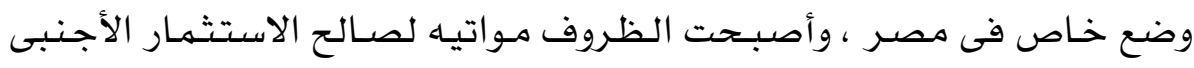

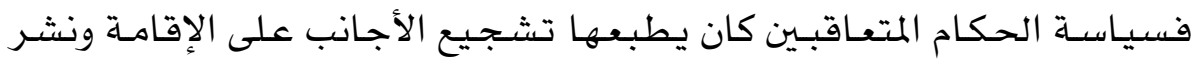


نشـاطهم فى مجالات الاقتصـاد المصرى ، وذلك بإعطائهم امتيازات وإعفاءات

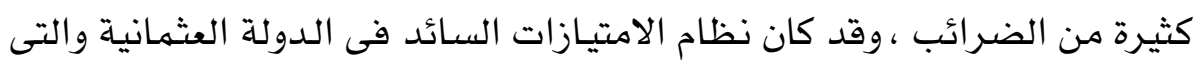

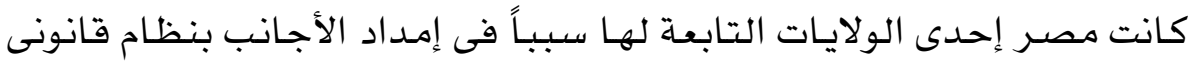

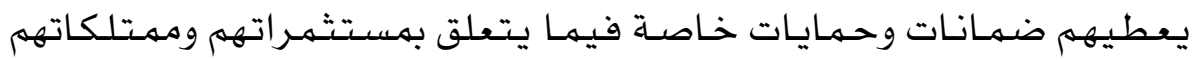

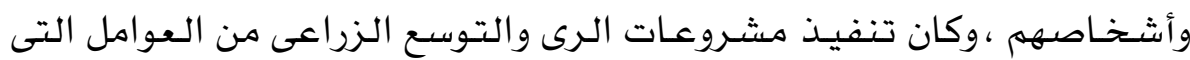

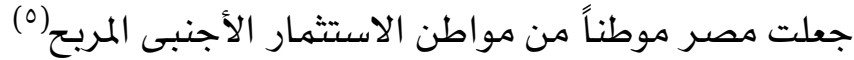
وعلى هـذا الأسـاس انتشـرت الكثير من الشـركات الزراعيـة التى امتلكها مسـاهـمـون أجـانب من مـتـلف الجنسـيـات من انجليز وفـرنسيـين وبلجـيكيـين

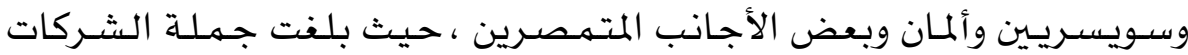

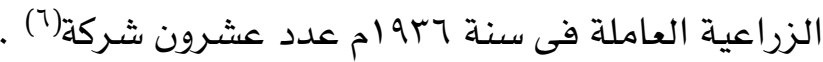
وكانت أكثرية شـركات الأجانب الزراعية شـركات مسـاهمة مصرية ،ولا يعنى

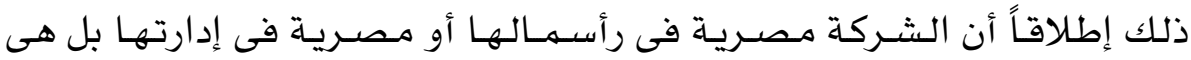

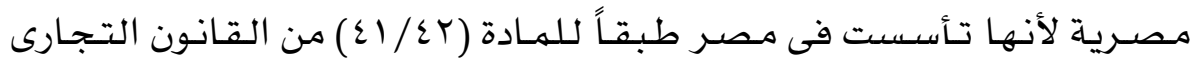

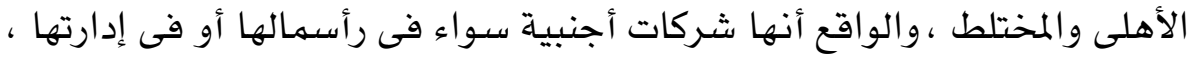
والمتصفح لوثائق مصلحة الشركات الخاصة بالشركات الزراعياة يتبين صدق هذه

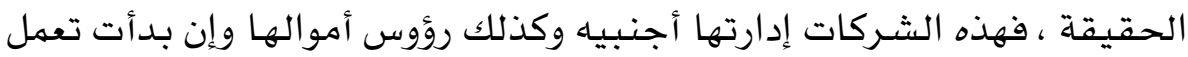

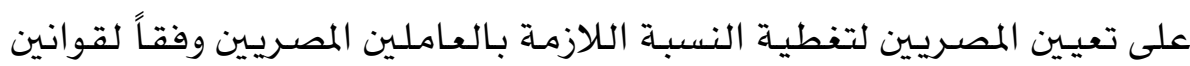

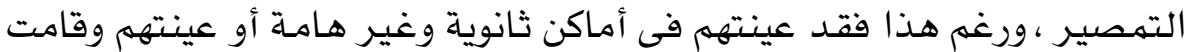
بفصلهم بعد ذلك(V) وعندما نتعرض للاستثمارات الأجنبية فى مجال النشاط الزراعى فى مصر

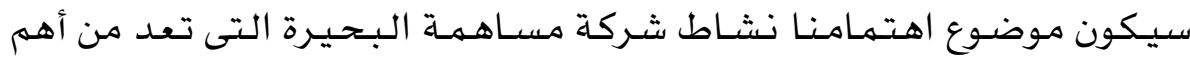

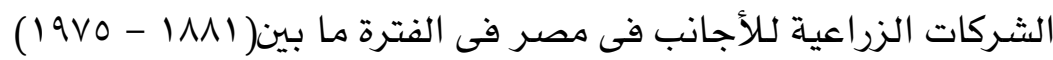
وذلك من خلال العناصر التالية :

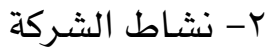

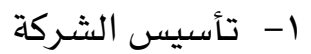


شركة مساهمة البحيرة ونشاطها الزراعى والصناعى فى مصر وخارجها (1111 - 19V0)

$$
\begin{aligned}
& \text { ع- الموظفون والعمال } \\
& \text { 7- تطور رأس مال الشركة } \\
& \text { 1- نشاط الشركة خارج مصر }
\end{aligned}
$$$$
\text { r - إدارة الشركة }
$$$$
\text { 0- م- التفاتيش الزراعية }
$$

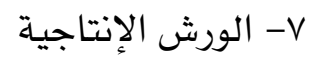

$$
\text { تأسيس الشركة }
$$

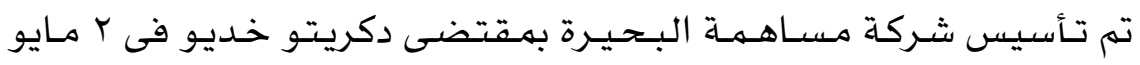

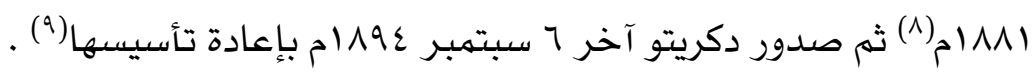

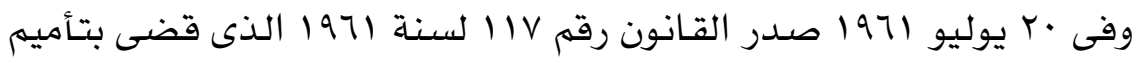

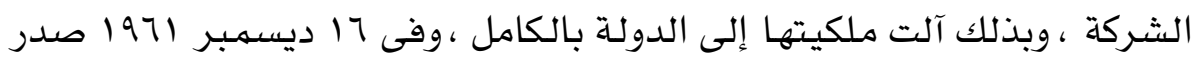

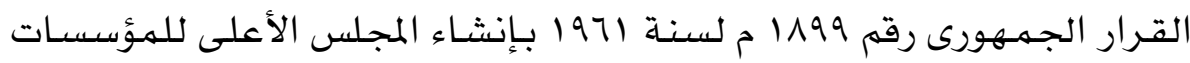

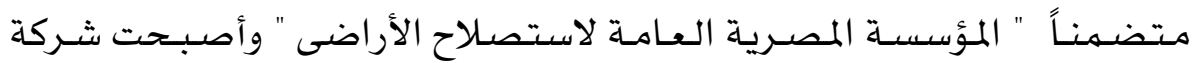

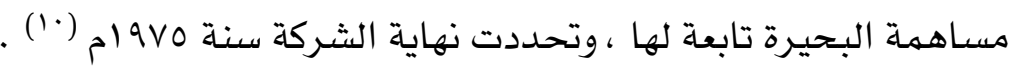
نشاط الشركة

كان ينحصر عمل الشركة فى أول تأسيسها سنـة 111ام على تغذية ترعتى

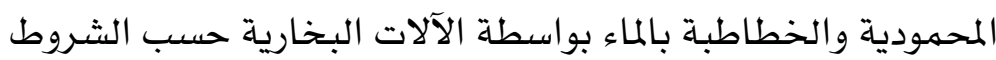

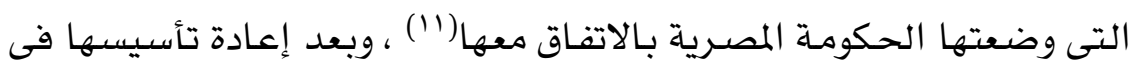

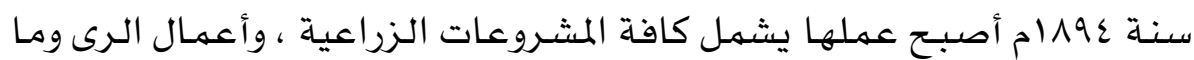

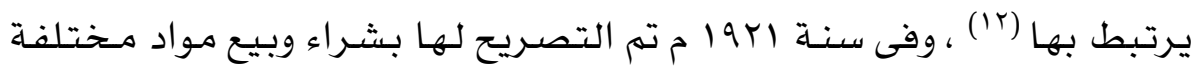
ومباشرة صناعة الآلات والأجهزة المعدنية ، والقيام بإصلاحها وإجراء العمليات

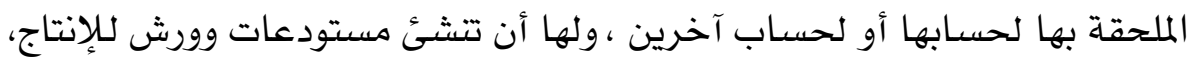

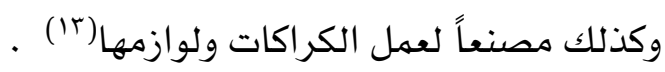
إدارة الشركة يدير الشـركة مجلس إدارة مؤلف من خمسـة أعضـاء وعلى الأقل ومن اثنى

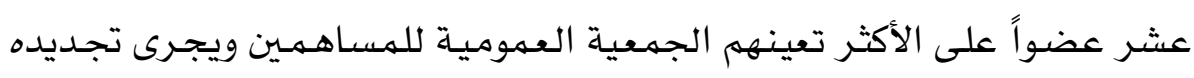


سنوياً بهعدل الثلث ، ويجب أن يكون كل عضو من أعضاء مجلس الإدارة مالكاً لمائتى سهم على الأقل .

ويججب أن يـجتهمع مجـلس الإدارة أربع مـرات على الأقل خلال الســـة المـاليـة

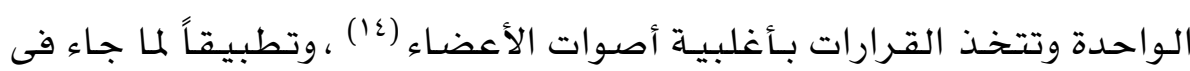

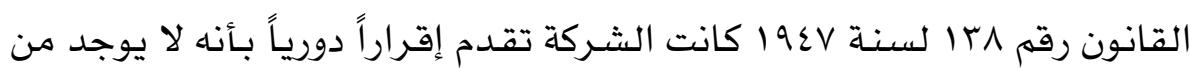

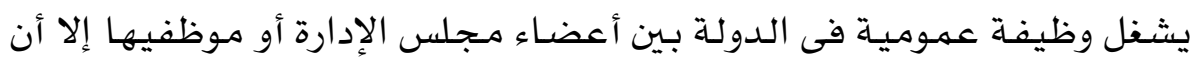
يكون قد ترك وظيفته أو أحيل للمعاش مثل عبد الجليل بك العهمرى وزير المالية

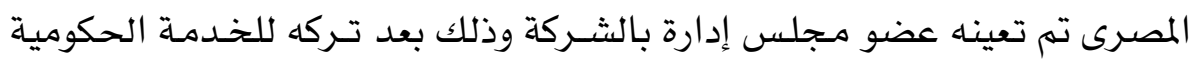

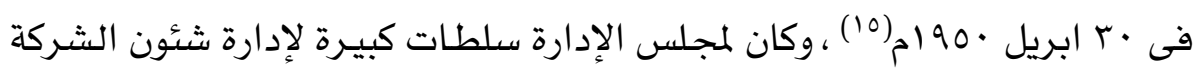

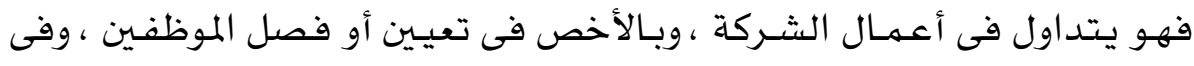

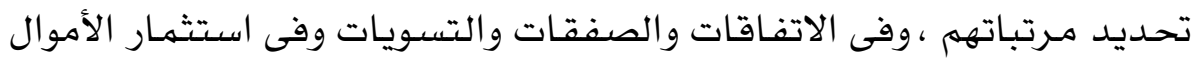

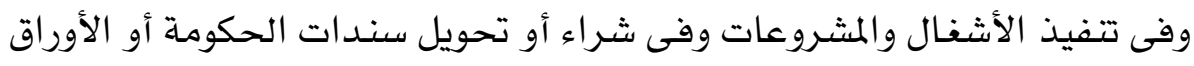

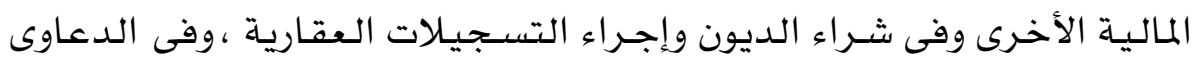
القضائية ، وبصفة عامة يتصرف مجلس الإدارة فى جميع الشئون المتعلقة بإدارة

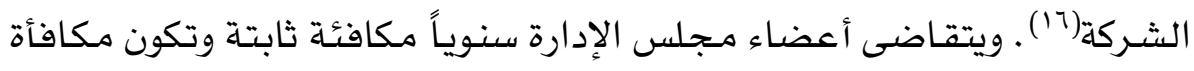

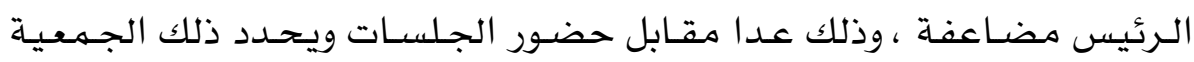

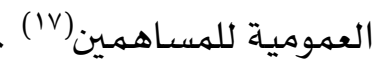
وسيطر الأجانب من الانجليز والفرنسيين واليونانيين على مجلس الإدارة،

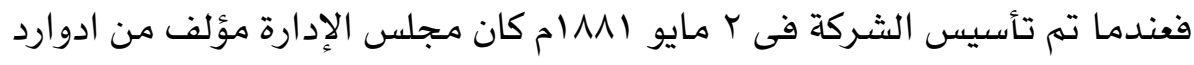

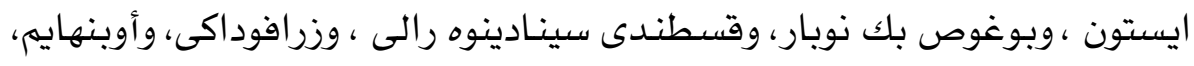

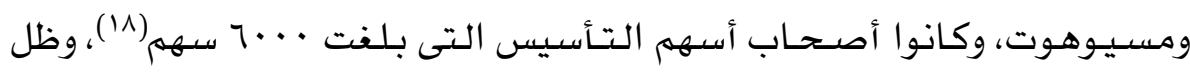

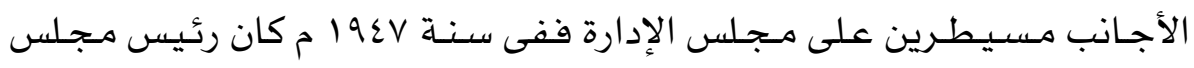

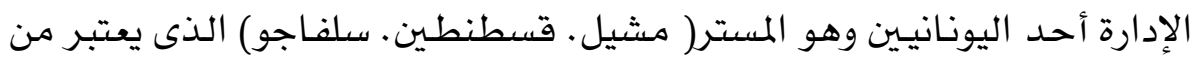

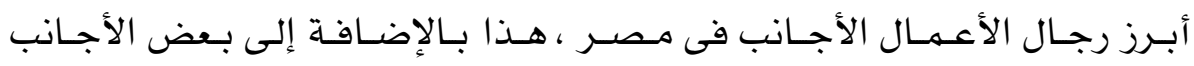

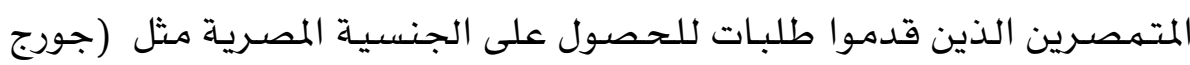


رباط - وهنرى رباط) وهما انجليزيان ،وفى سنة 90 ام كان فى مجلس الإدارة

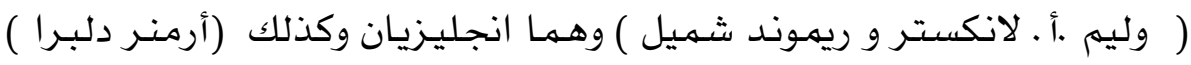

ومع اتجاهات تمصير النشاط الأجنبى وظهور القوانين ألزمت الشركات

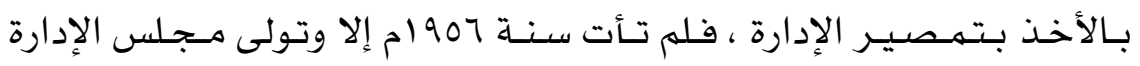

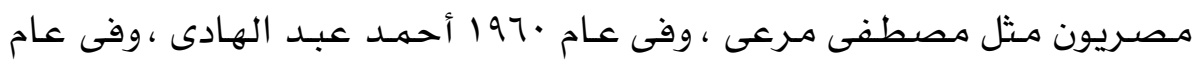

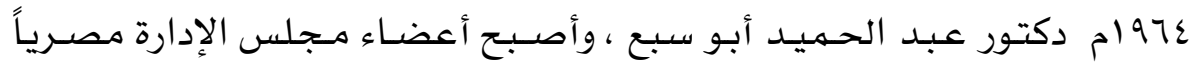

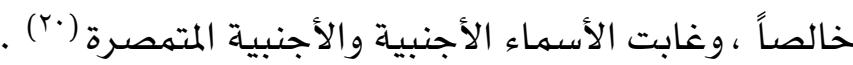
وكان للشـركة جهعيـة عمهومية مكونة من جهيع المسـاهــين والذين يهتلكون عشرة أسهم على الأقل ، وكانت تدعى للانعقاد مرة واحدة فى السنة في موعد لا لا

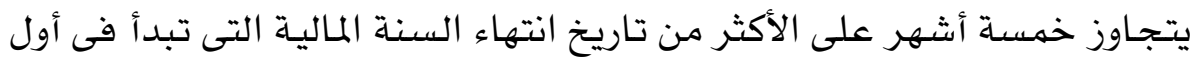

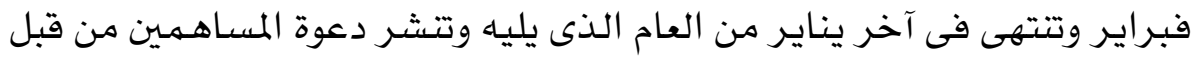

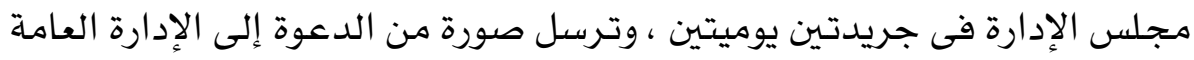

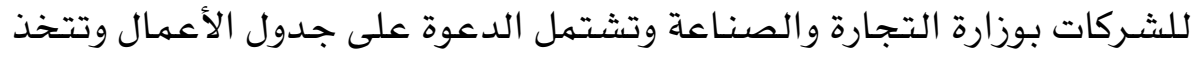

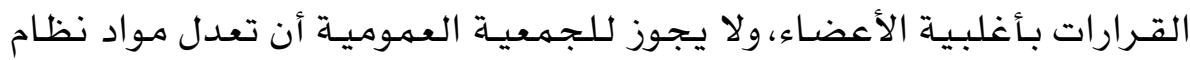

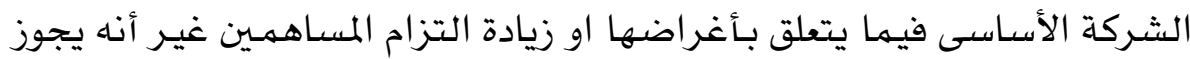

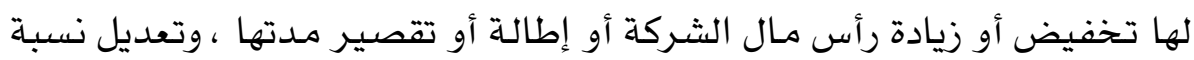

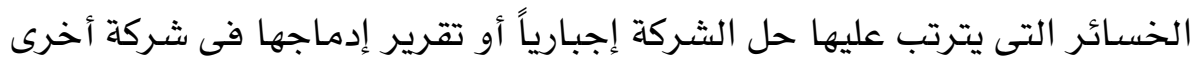

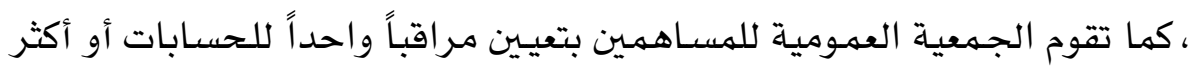

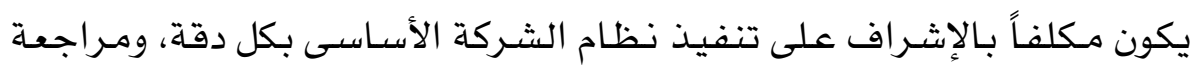

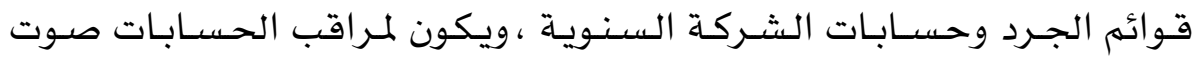

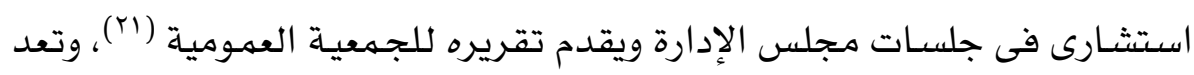

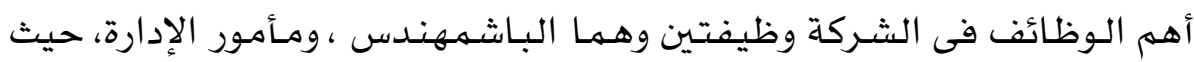
يكلفان من قبل مجلس الإدارة بتحرير صور العقود وتنفيذهـا وتتظيم الأعمال 
والأشغال ويقومان بتعيـين الموظفين وعزلهم وتقدير رواتبهم وينوبان عن مجلس

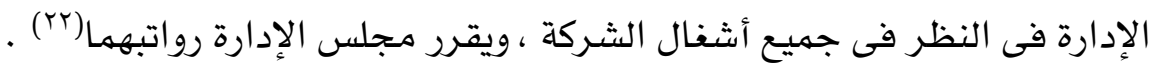

وأمـا بالنسبـة للموظفين بالشركة فكان للأجـانب اليد الطولى فتولوا الأقسام

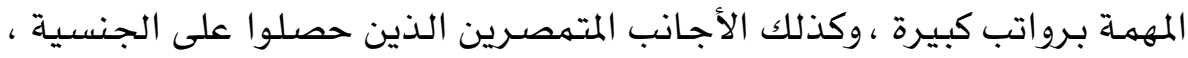

وقليل من المصـريـين ولكنهـم فى وظائف الكتبـة المسـاعدين مدثل جـوزيف جمال

مصرى يعهل كاتب السكرتير وهصريـين آخرين يعملون مسـاعدين للصـراف

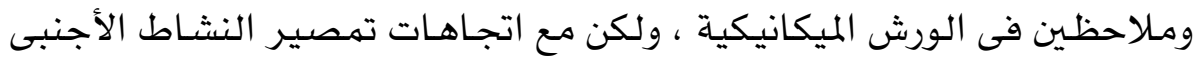

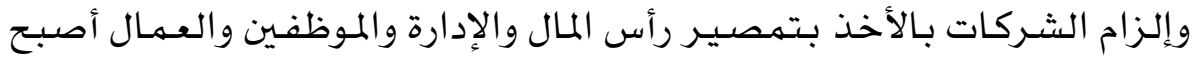

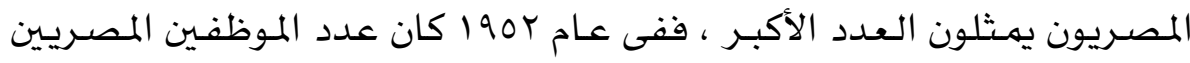

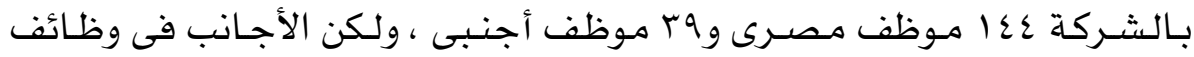

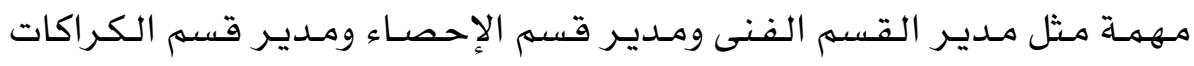

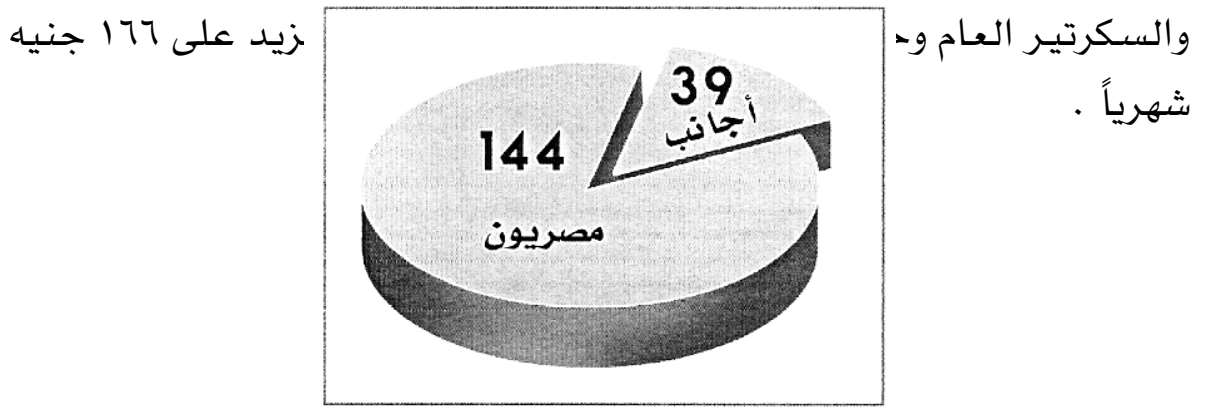

شكل (1)

( نسبـة عـدد الموظفـين المصـريـين للأجـانب عـام 190r بعـد إلزام الشـركة

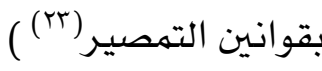

وأما بالنسبة للعمال فى الشركة فكانوا فى الأعم الأغلب من المصريين وكانوا

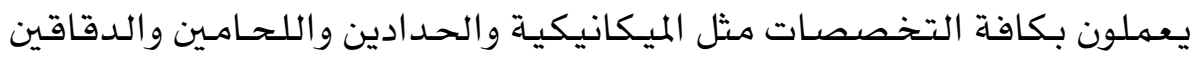


والطبـاخـين والسـائقـين والخـراطين والزيـاتين والنـجـارين والملاحظـين والخفـارة

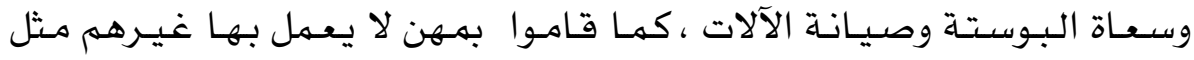

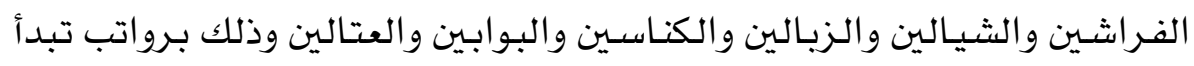

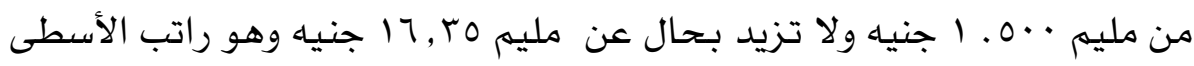

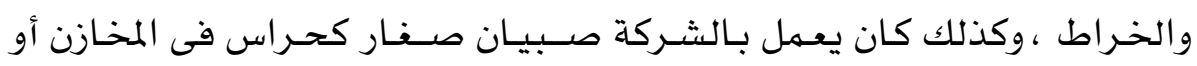

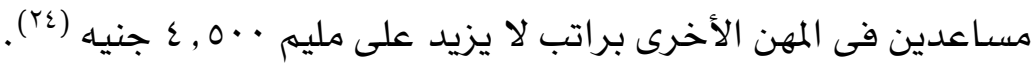
أضف إلى ذلك عمال التراحيل الذين كانوا يعملون بـاليومية في الأعمال

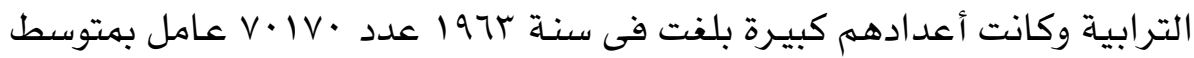

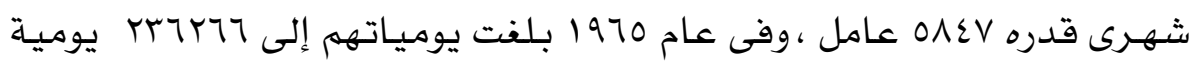

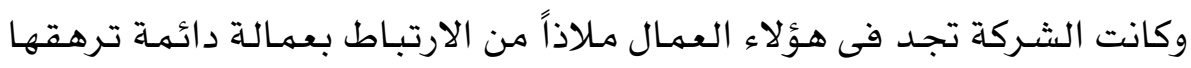

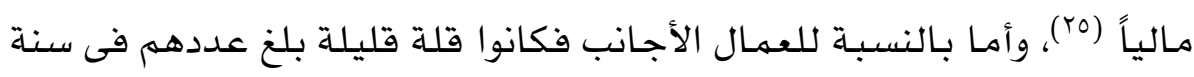
• 190 سبعة عمال ،وفى سنة 1900 تسعة عمال ، وكانوا في مهن وأعمال خفيفة

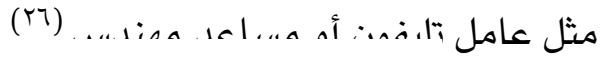
( 197 عدد العمال

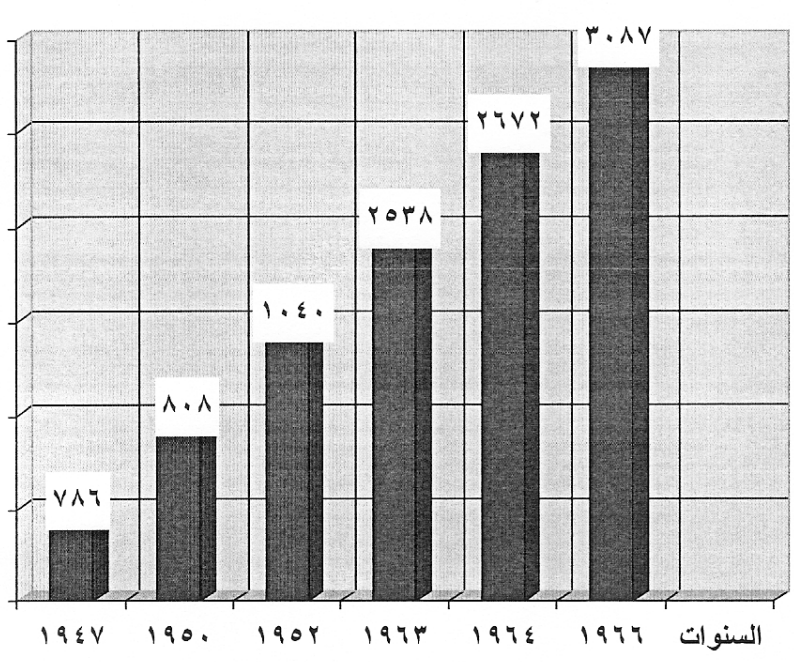
وفيما ! 


\section{شكل (}

(TV) ( $1977-19 £ V$ عدد عمال شركة مساهمة البحيرة فى الفترة )

وزيادة العهال كما بالشكل رقم ( r ) يرجع للأسباب التالية :

الأول :- كثرة الأعمـال التى احتاجت الشـركة فيها إلى عمـال دائمـين وبلغ

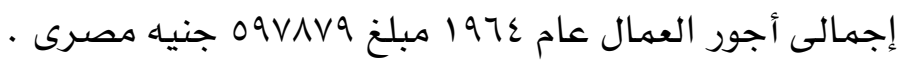

الثـانى :- ألزمت القـوانين الشـركة بـاتخـاذ الإجـراءات الكافيـة التى تكفل

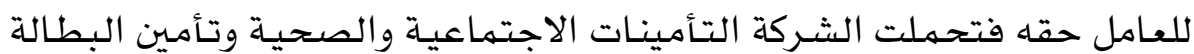

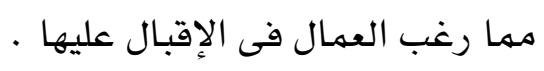

الثالث :- قـامت الشـركـة فى عـام (1972 / 1970) بتطبيق أحكام لائحة

العاملين بالشركات التابعة للمؤسسات العامة الصادرة بالقرار

الجمهورى رقم roع7 لسنة ror 197 ، وتم تسكين جميع العاملين فى وظائفهم

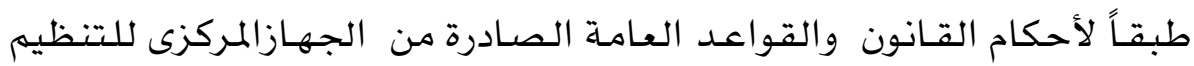

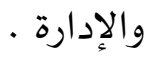

الرابع :- كان للعهال حصة من الأرباح السنوية للشركة تقسيم كالتالى

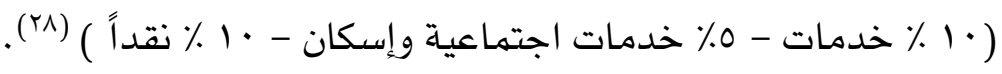

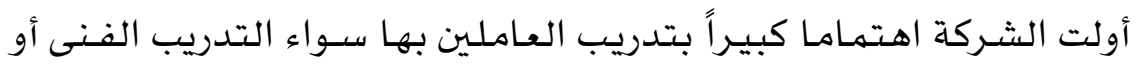

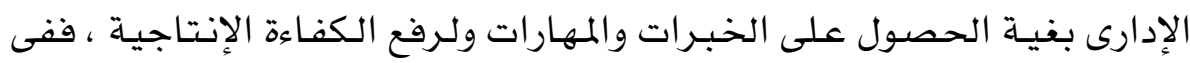

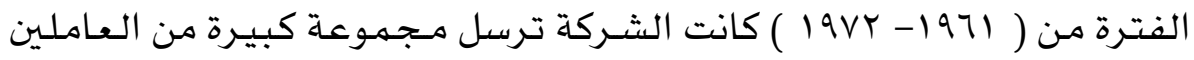

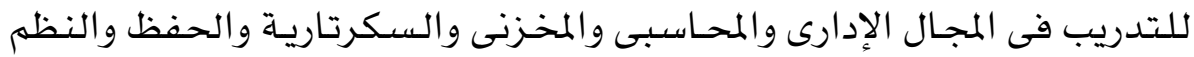

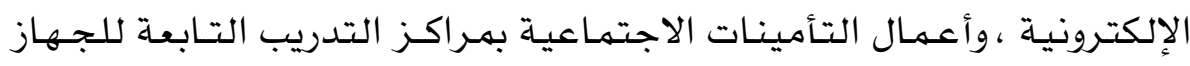

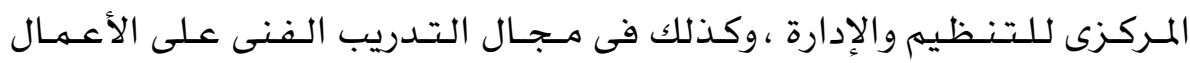

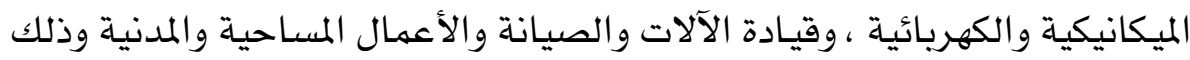
بمراكز التدريب التابعة للمؤسسة بدار السـلام ،ومراكز تدريب جاناكليس التابع 
لمؤسسـة تعمير الأراضى ،وكذلك مركز تدريب شـركة النصر لصنـاعة السيارات ومصلحة الكفاية الإنتاجية (r9) .

وإيماناً مـن الشـركة بضـرورة ربط العـاملين بها وتوعيتهم بالسياسـة العـامـة للدولة ،وبـدور كل عـامل فى الإنتاج ، قـامت بالتعـاون مع أمـانـة العمـال بـالأمـانة العامـة للإتحاد الاشتراكى العريى بإنشـاء مركز للدارسين السياسيـين بالشـركة

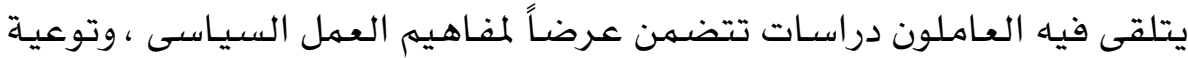
العامل بـدوره فى الإنتاج لكى ينعكس ذلك على سـلوك العاملين ويؤثر فى زيادة

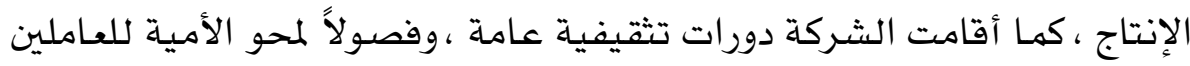
بالورش الإنتاجية ومناطق استصـلاح الأراضى ، وذلك بالتعاون مع اللجنـة النقابية

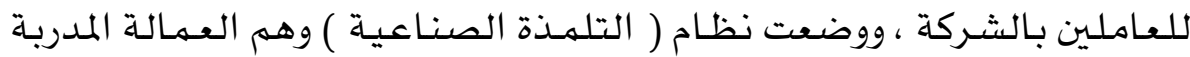
ضماناً لاستهمرار كفاءة التشغيل فى الورش الإنتاجية (·r). وفى عـام ع7 97 ابـدأت الشـركة فى الاهتهـام بالنـواحى الترفيهية للعاملين فنظمت رحلات عديدة للتعرف على معالم نهضـة مصر الحديثة ، وكذلك نظمت

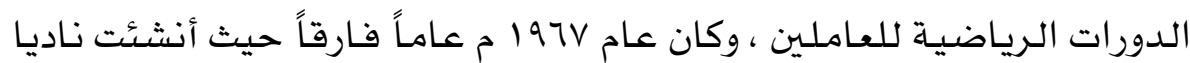

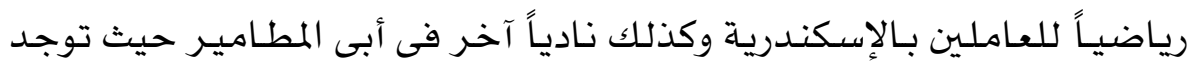

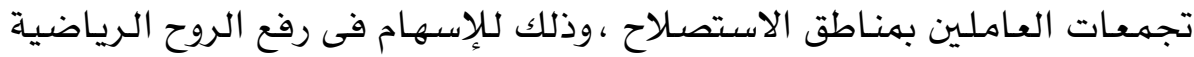

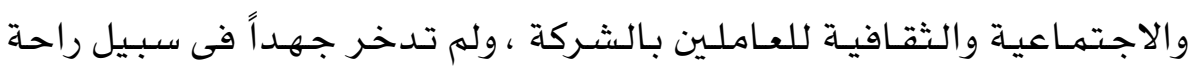

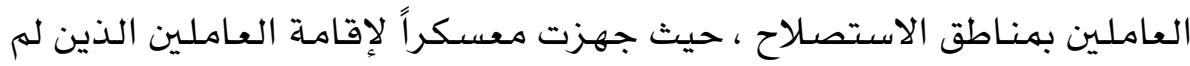
تستوعبهم مدينـة أبى المطامير، وأقامت مستعمـرة لإقامـة المهندسـين والإداريين

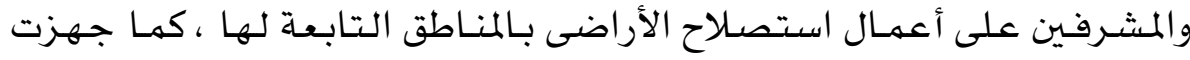

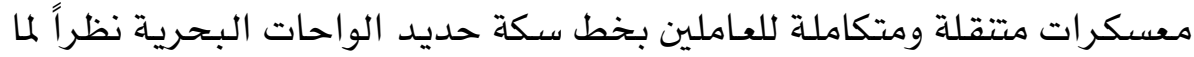
يقتضيه العمل فى المشروع من التوغل إلى مسافات كبيرة داخل الصحراء(الت) . وكانت الشـركة تهتم بـالشــون الصـحيـة للعـاملين ، ولـذلك اهـتمت بإنشـاء مؤسسة طبيـة من ذوى الكفاءة والخبرة للعمل بهناطق التفاتيش الزراعية التابعة 
للشـركة ،وكانت تعلن عن حـاجتها للأطبـاء فى الجرائد الرسـميـة وتجرى لهم

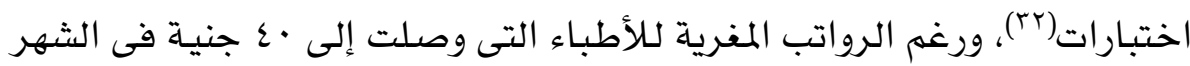

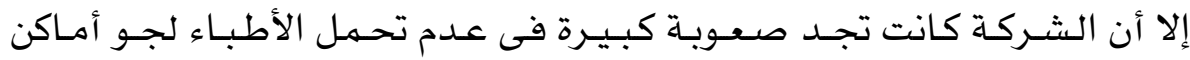

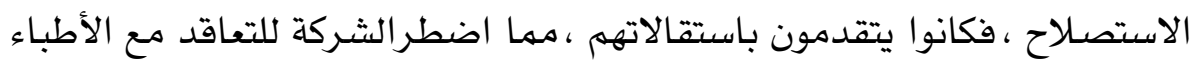

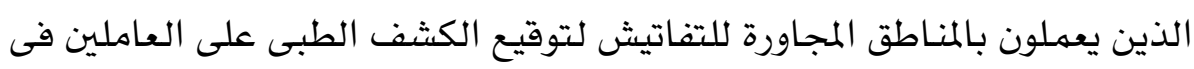

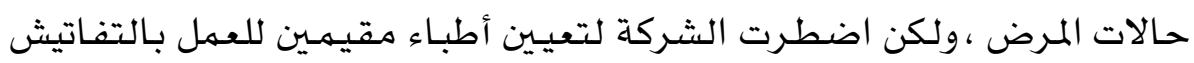

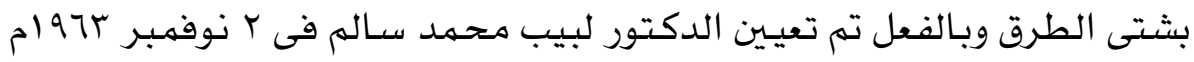

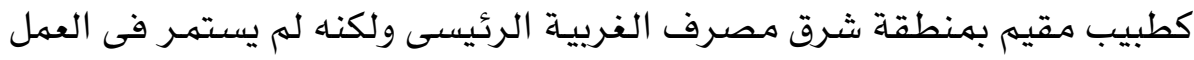
أكثر من شهرين وقدم استقالته فى ا يناير 1972 م ، وأمام تزايد عدد العاملين

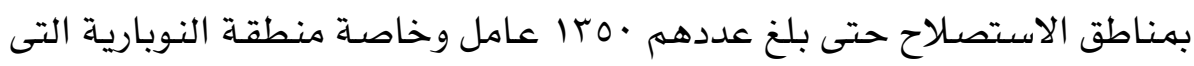

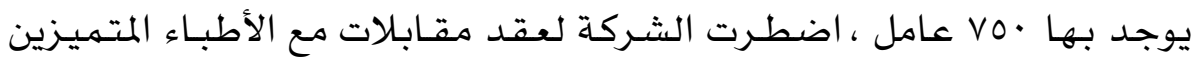

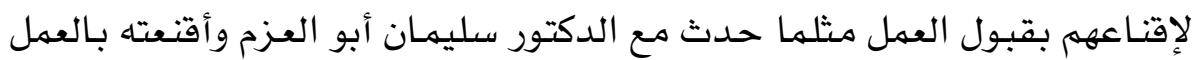
بهنطقة النويارية وأعفته من الاختبار (rr) .

وحرصاً من الشركة على حماية عمالها من أخطار المهنة والإصابات ، فقامت

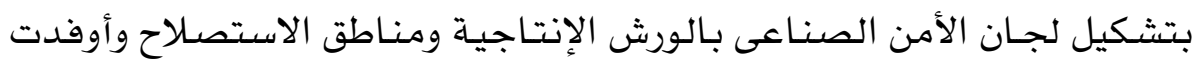

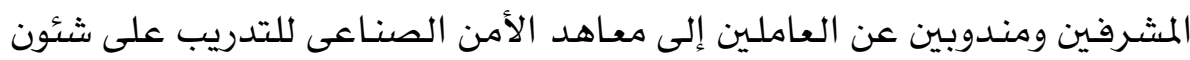

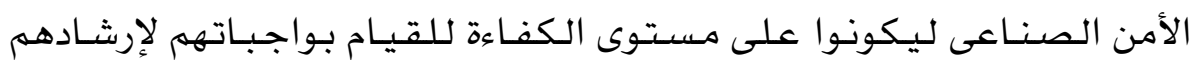
بالواجبات والتوجيهات والعمل على الإقلال من الحوادث والإصـابات(عَّ) . وقامت الشـركة بإدخال النظم الإلكترونية فى حسـابات وأعمـال التفاتيش

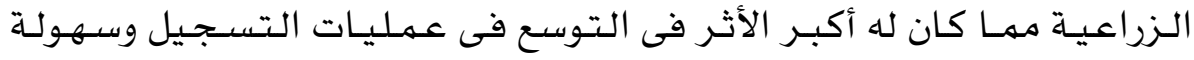
التحصيل والإسـراع فى تصفية التفاتيش الزراعية وإلغاء غالبية الأعمال اليدوية

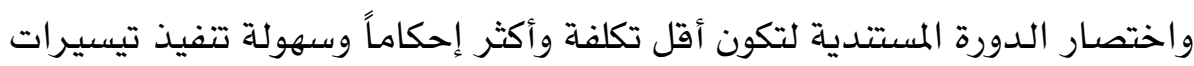

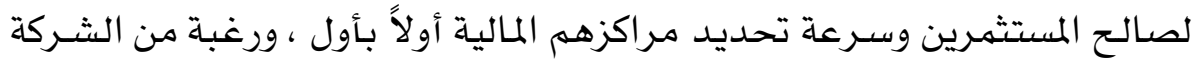

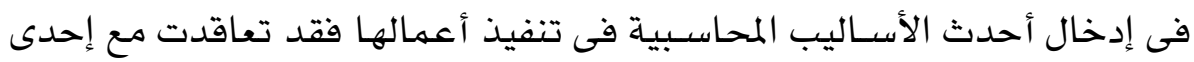

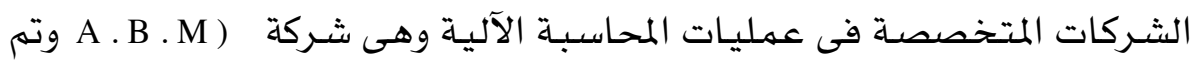


تفعيل ذلك فى عام 970 ام وثبت نجـاح هـذا النظام وتأكدت فائدته بالرغم من النمات الجهد الثاق الذى استلزمها وضع النظام وتطبيقه للمرة الأولى (ro) .

وكان للشـركة دور كبير فى العمل الاجتماعى الخيرى ، فكانت تتبرع لجمعية

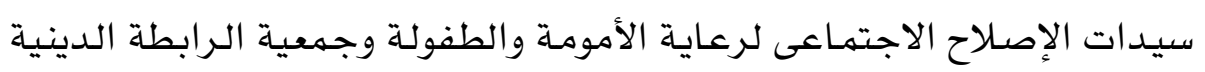

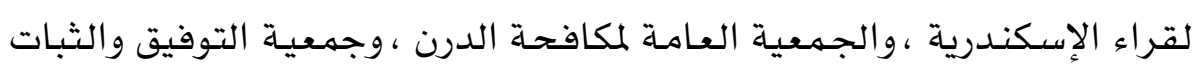

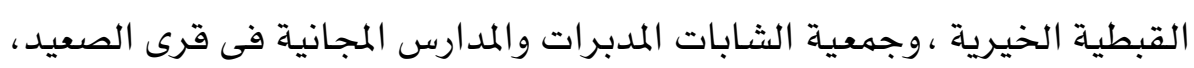

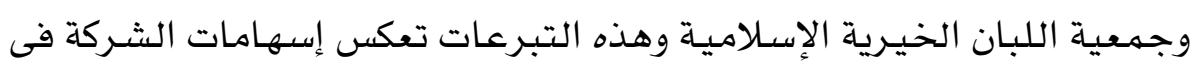

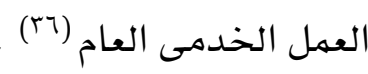
التفاتيث الزراعية كانت الشـركة تضمى أربعة أفرع وهى فرع الورش العامة، وفرع الكراكات، وفرع

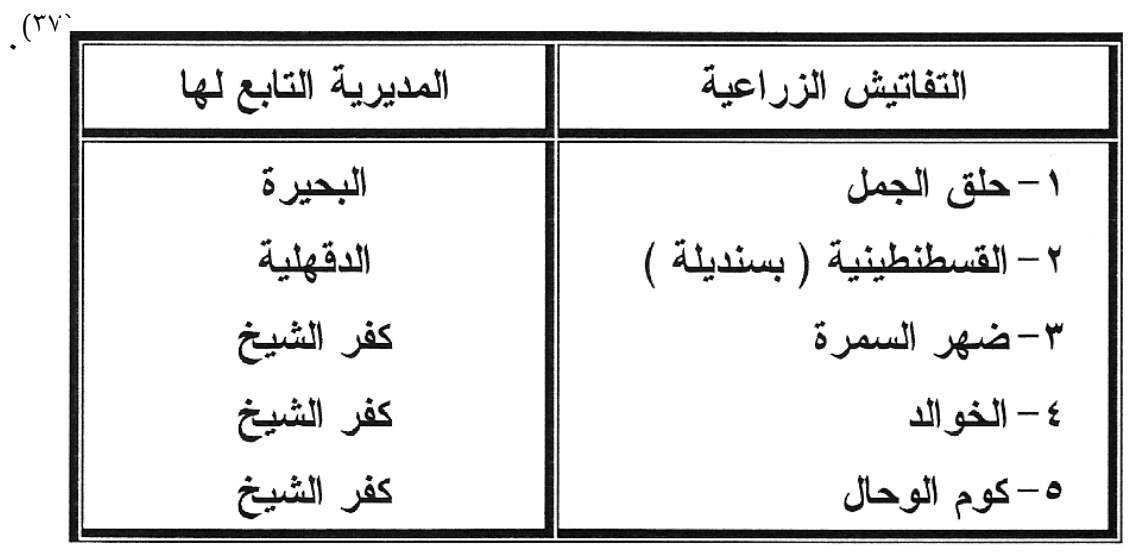

كانت هذه التفاتيش تضم أطياناً زراعية اهتمت الشركة بزراعتها بالمحاصيل

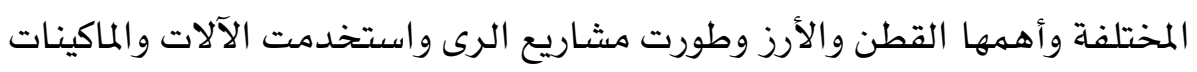

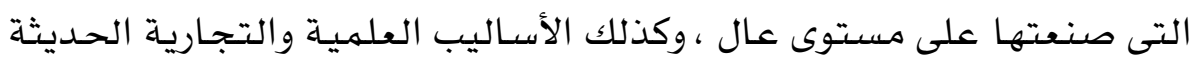

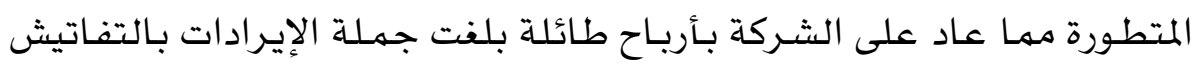

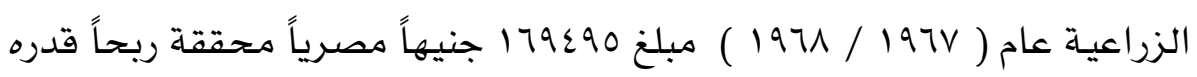




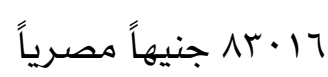

وكانت الإيرادات فى زيادة مستمرة ويرجع ذلك إلى :

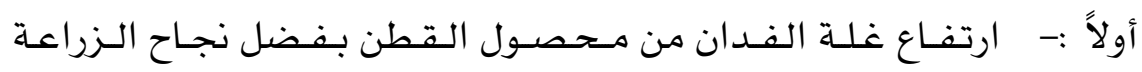

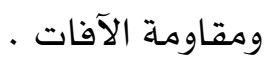

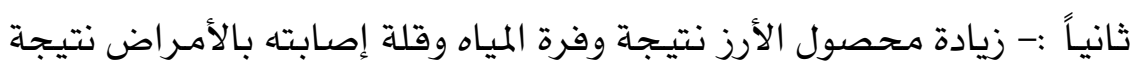

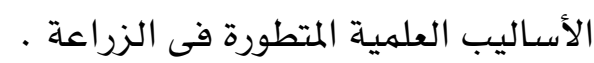

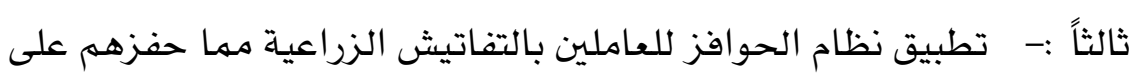

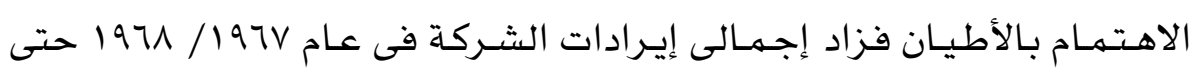

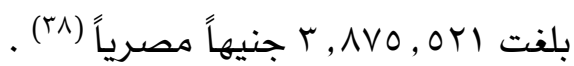

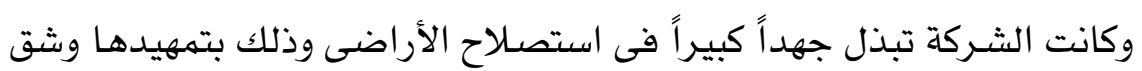

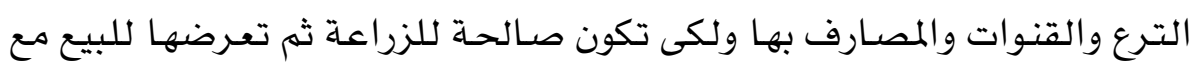

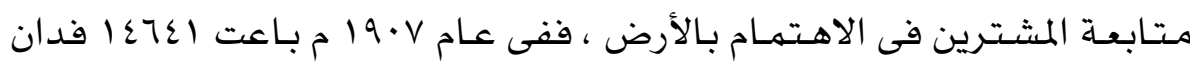

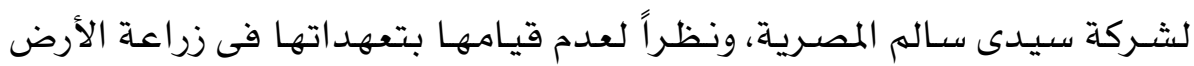

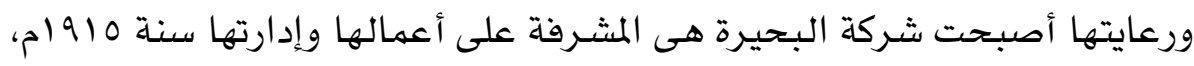

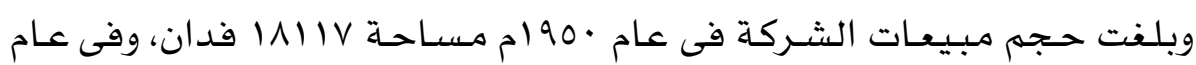

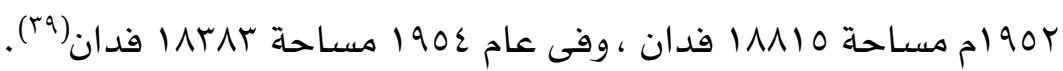
وكانت الشركة تقوم بعملية البيع لهذه الأطيان والتيسير على المشترين عن التهن

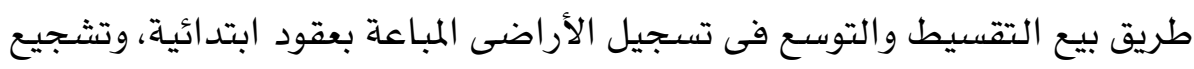

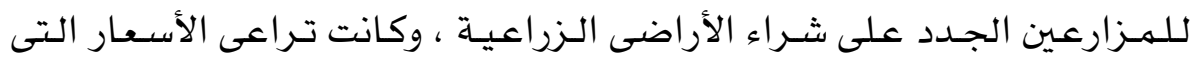

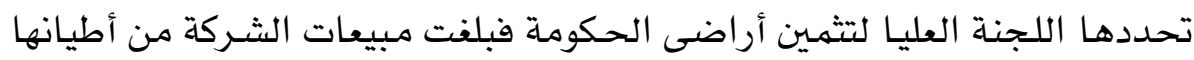

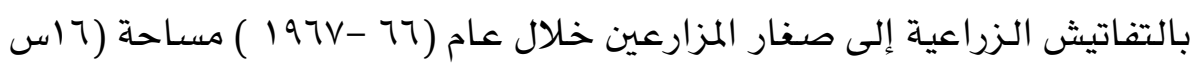

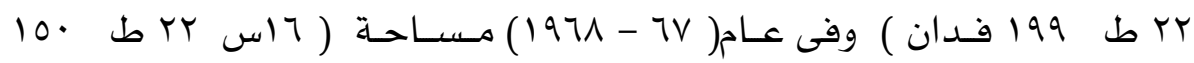

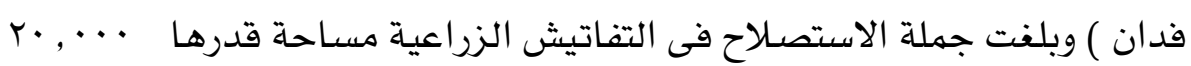


فدان وكانت هناك أطيان أخرى مشغولة بالمنافع العامة للدولة(•) .

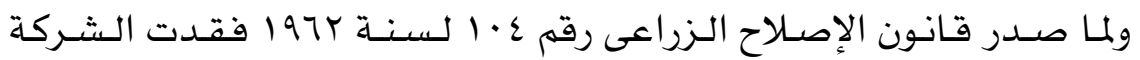

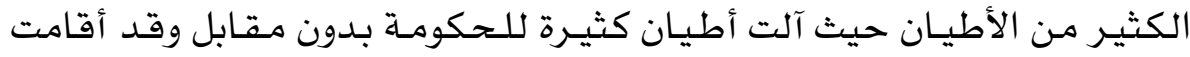

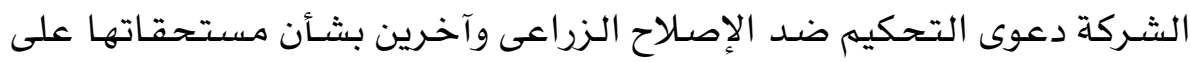

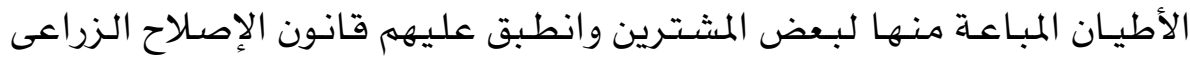

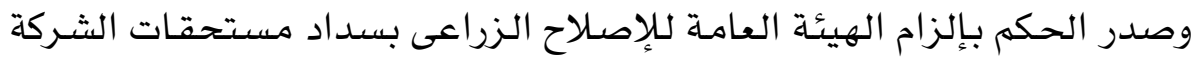

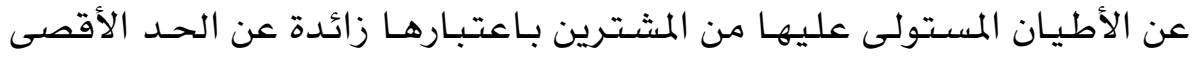

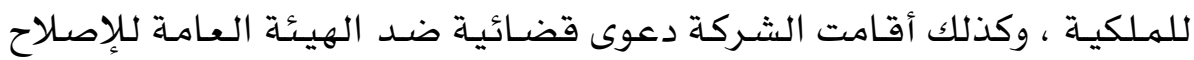

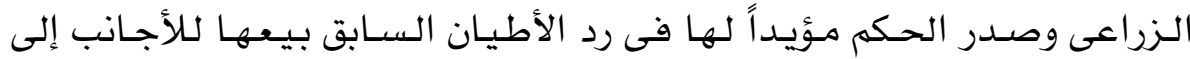

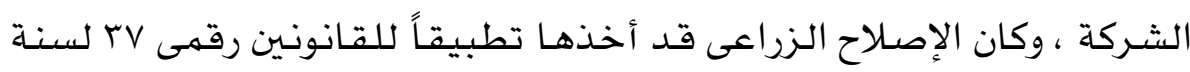

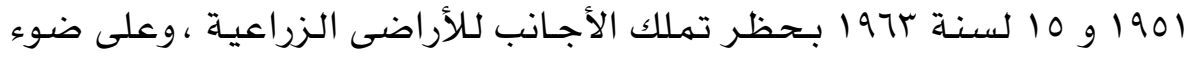

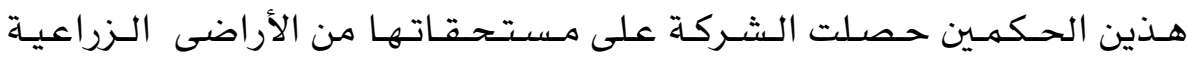

بتفاتيشها المختلفة( (1).

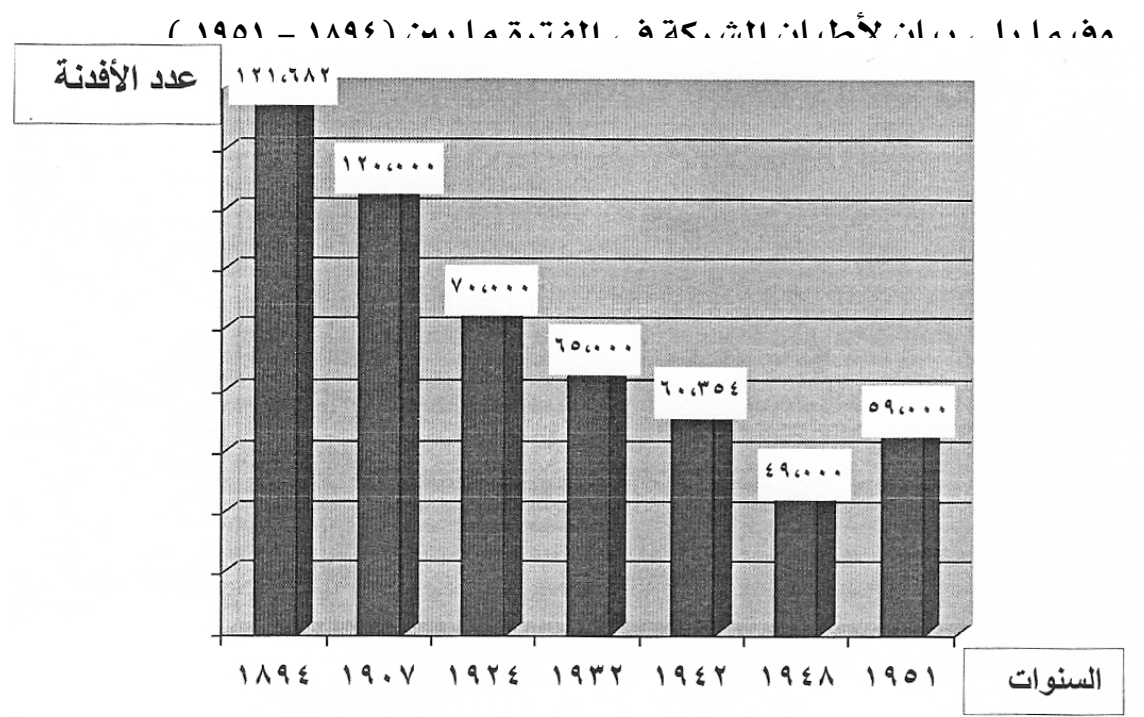




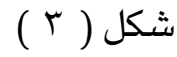

من الشكل يتبين التتاقص التدريجى الواضح فى أطيان الشركة ،وما ذلك إلا لنشاط عملية البيع حيث كانت الشركة تعطى تسهيلات كبيرة فى التقسيط لفترة

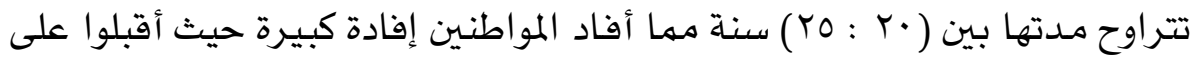

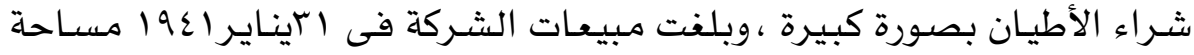
قدرها V97ll 1 فدان بالتقسيط على أمد كبير (Yع).

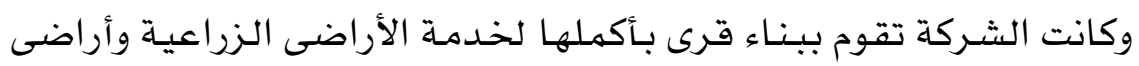

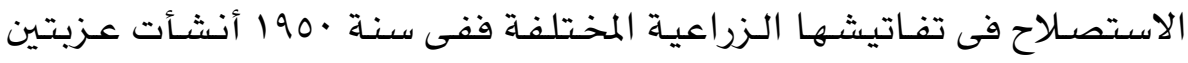
لخدمـة مسـاحة • ^ع فدان بتفتيش حلق الجـمل وجعلها صـالحة للزراعة وقامت

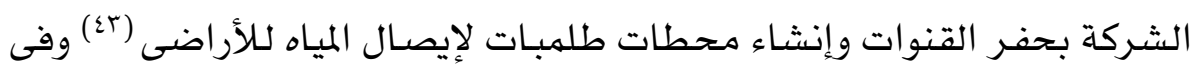

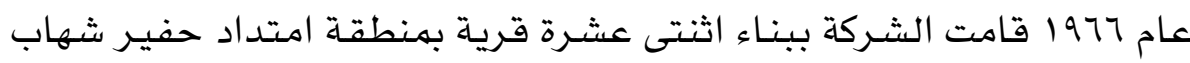

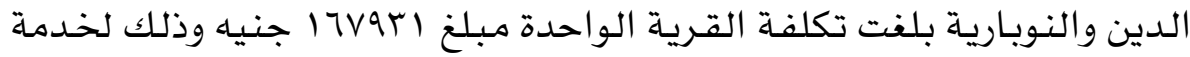

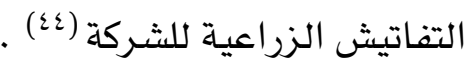

ومن الأعمال الجليلة التى قدمتها الشـركة تأجير الأراضى الصالحة للزراعة

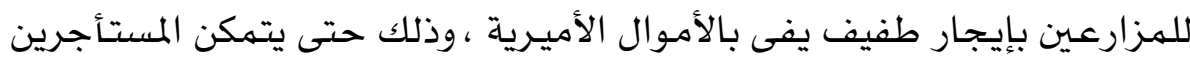

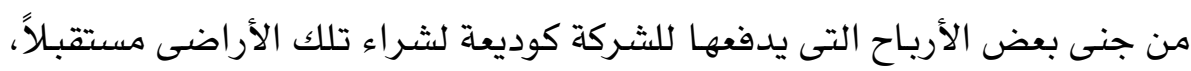

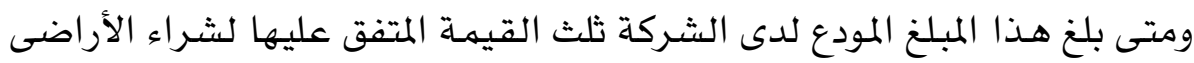
يمكنه أن يستجل البيع ويدفع بقية الثهن على أقسـاط سنوية تتراوح مدتهـا بين ( MO: Y·)

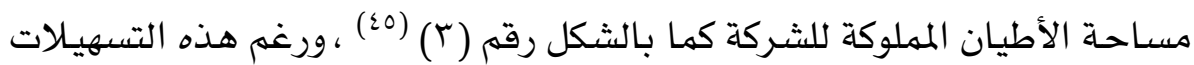

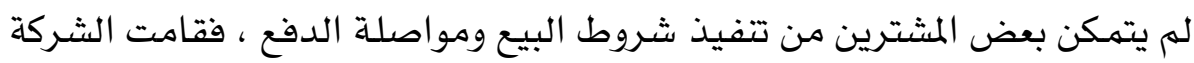

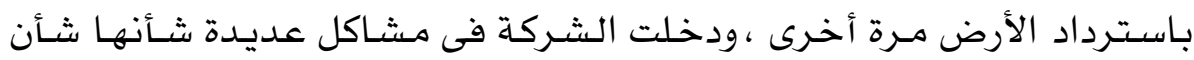

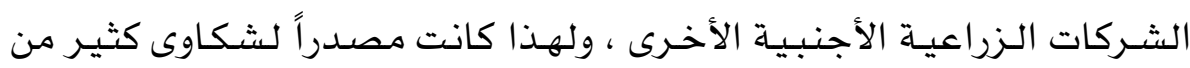

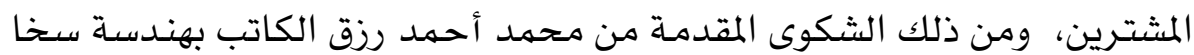


الميكانيكية، الذى اشترى ع ا فدان بالتقسيط بجهة تفتيش الخوالد، ولكنها كانت

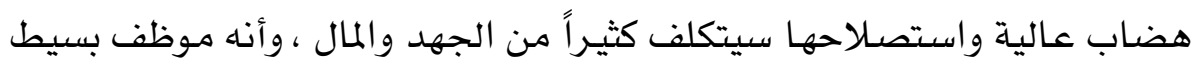

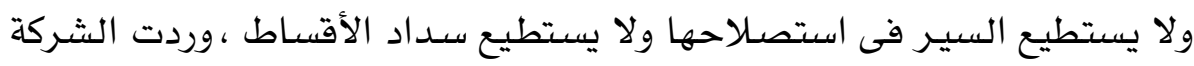

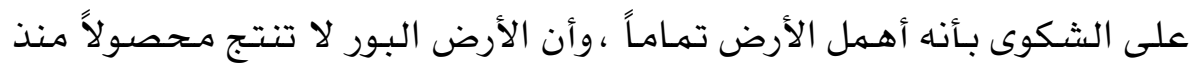

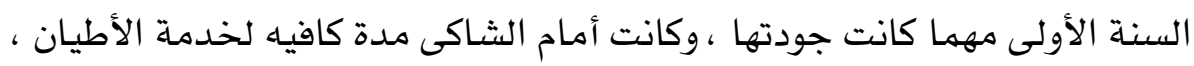

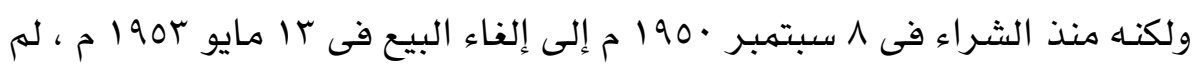

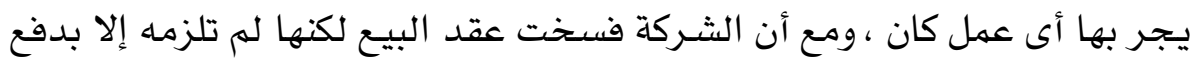

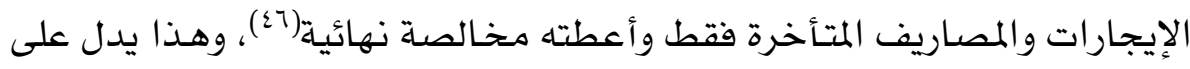

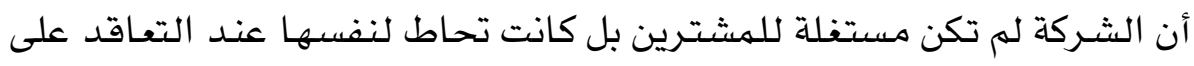

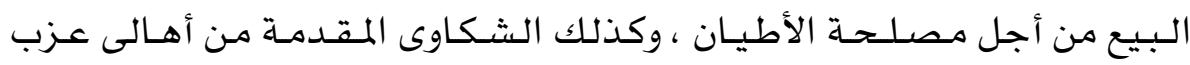
الرصيف ضد الشركة بأنهم تقدموا لشراء أطيان وتعهدت الشركة بالوكالقيام بأعمال

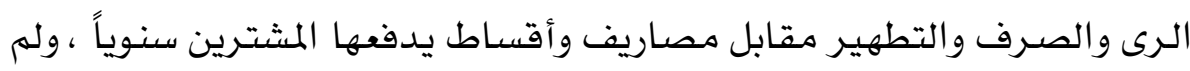
توف الشـركة بذلك مها تسبب فى بوار الأرض وأصبحت تالفة ،ولا تقوم بمؤنه

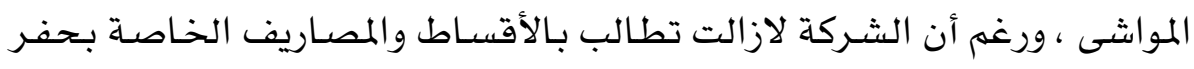

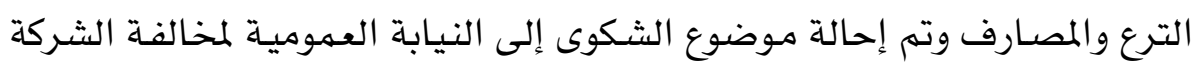

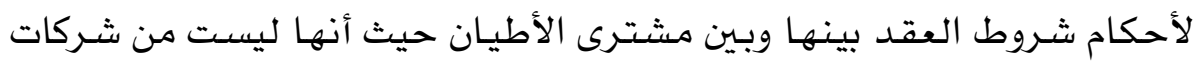
الامتياز) (2v)

وكانت الشكاوى المتكررة سـببـاً فى إنشـاء قسهم خاص بهـصلحة الشـركات

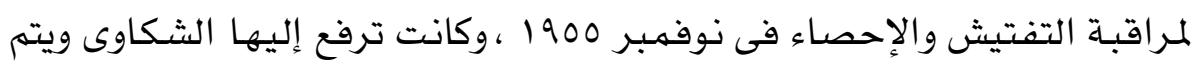

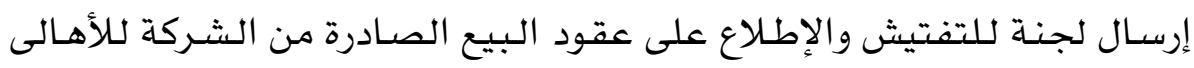

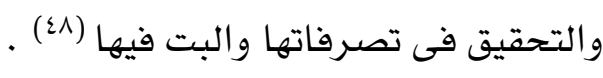
تطور رأس مال الشركة

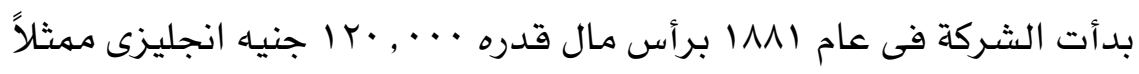

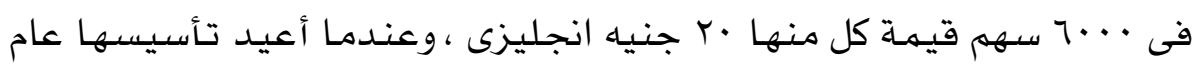




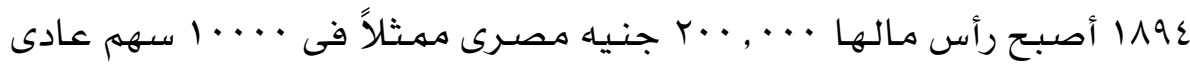

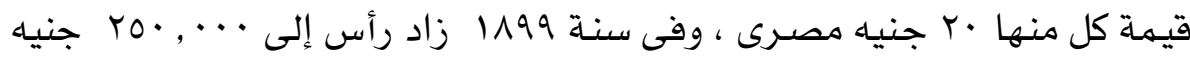

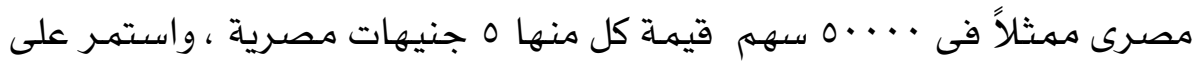

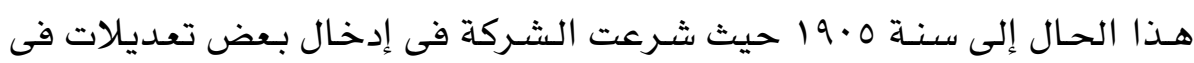

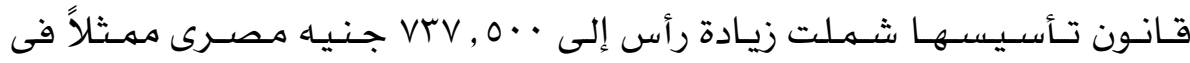

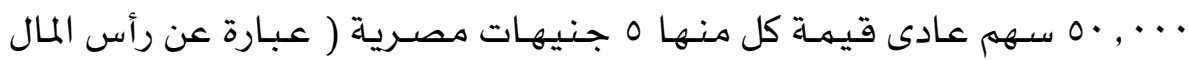

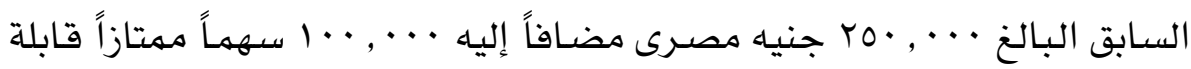
للاستهلاك بطريق الستحب بواقع م جنيهات انجليزية لكل منها أى ثمن قدره

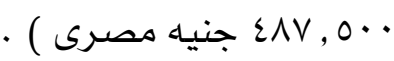

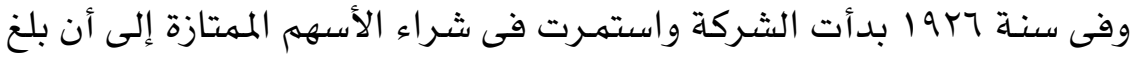

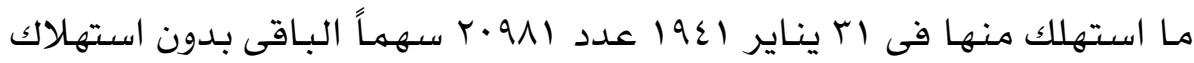

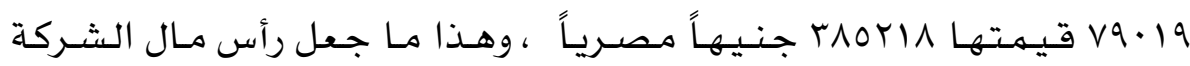

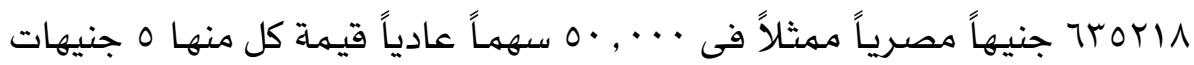

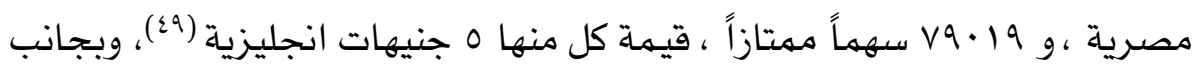

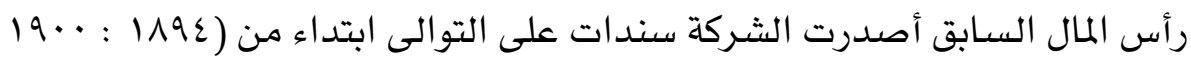

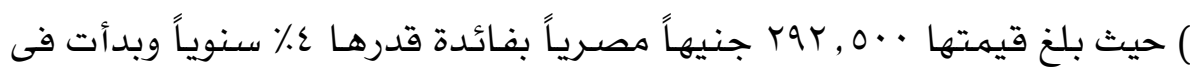

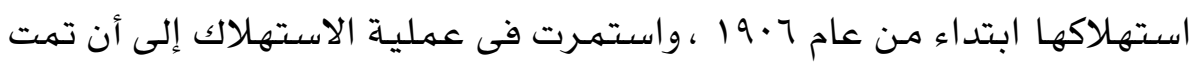

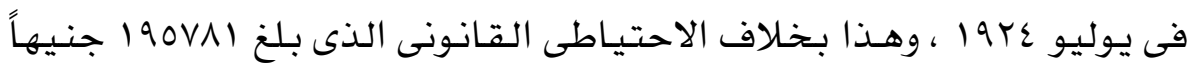

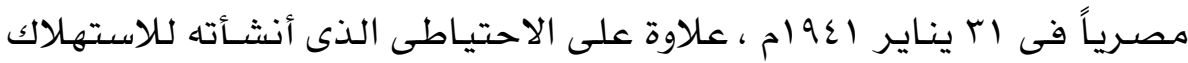

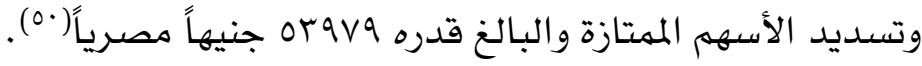

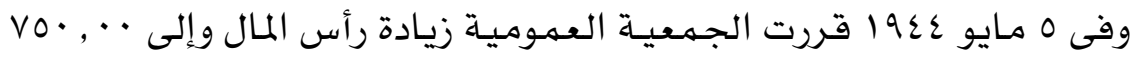

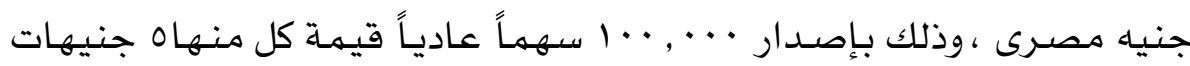

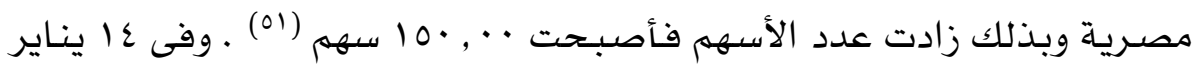

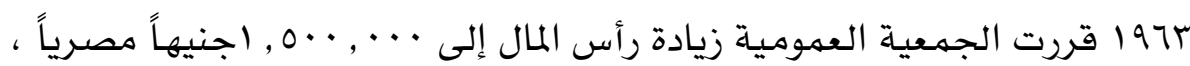

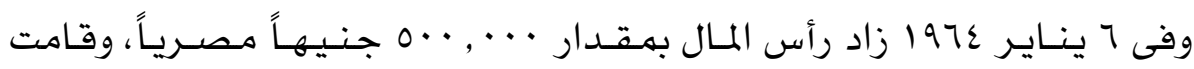


المؤسسـة المصـرية العامـة لاستصـلاح الأراضى بـدفع هـذه الزيادة على دفعتين ،

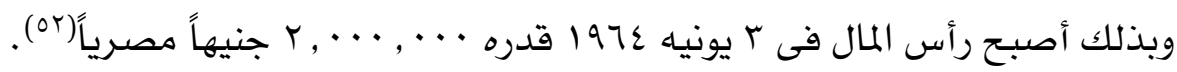

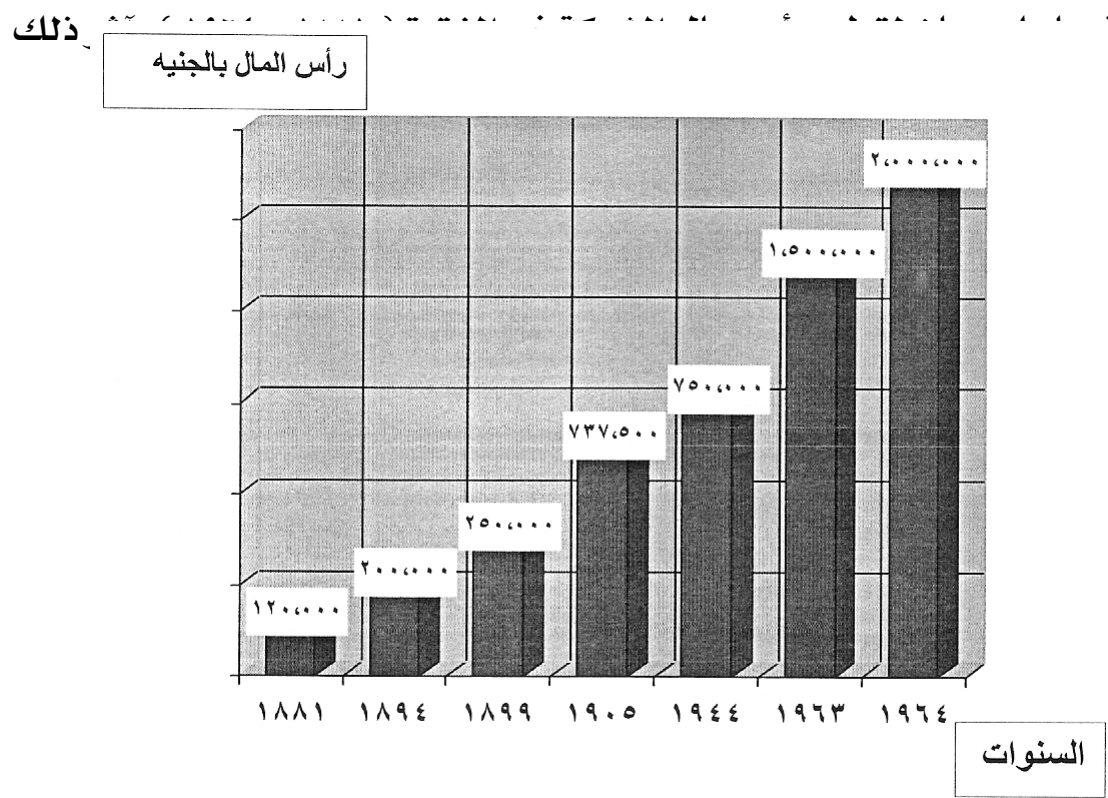

(شكل يوضح تطور رأس مال شركة مساهمة البحيرة منذ تأسيسها (1111 -

وهـذا الشـكل يبـين زيـادة رأس مـال الشـركـة بـدرجـات كبيـرة مهـا يـدل على

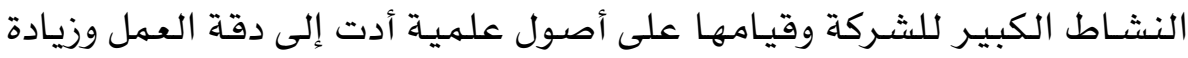
الإنتاج وكان وراء هـذا إدارة قويـة ذات خبرة عاليـة كانت محل ثقة الآخرين فكان هنـاك إقبال كبير على شراء الأسهـه خاصـة فى فترة الخمسينيات والستينيات

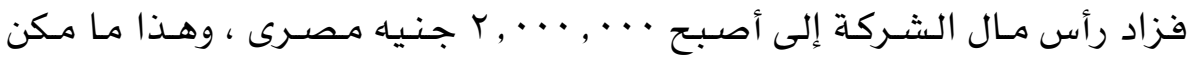


الشـركة من عقد مقـاولات كبيرة وعقود تصنيع بهبالغ ضخمهة وجعلها محل ثقة

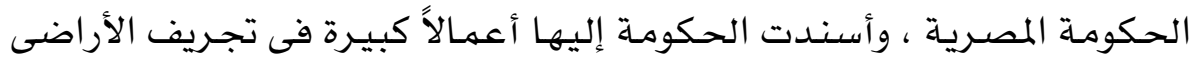

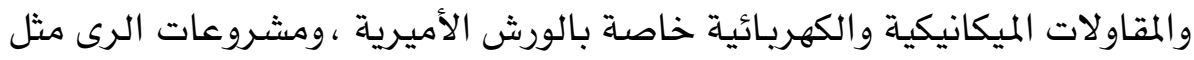

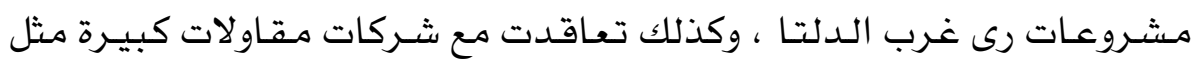

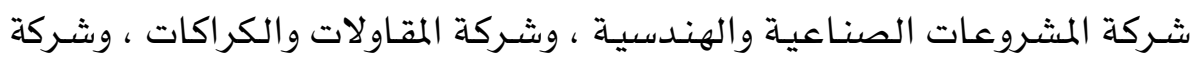

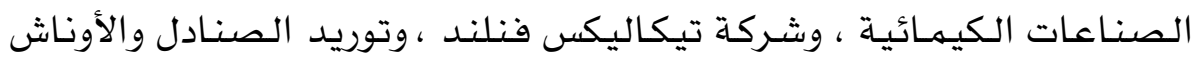

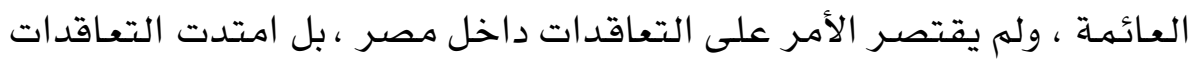

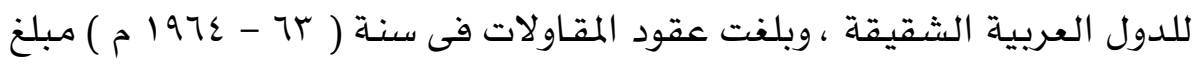


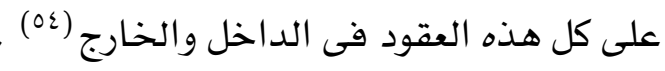
وسـارت الشركة على سياسـة مالية سليمـة وقويـة حيث وازنت بين متطلباتها

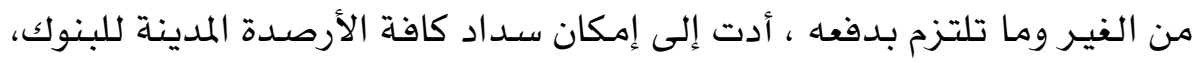

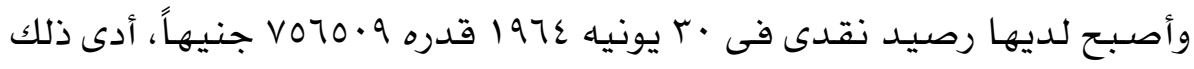

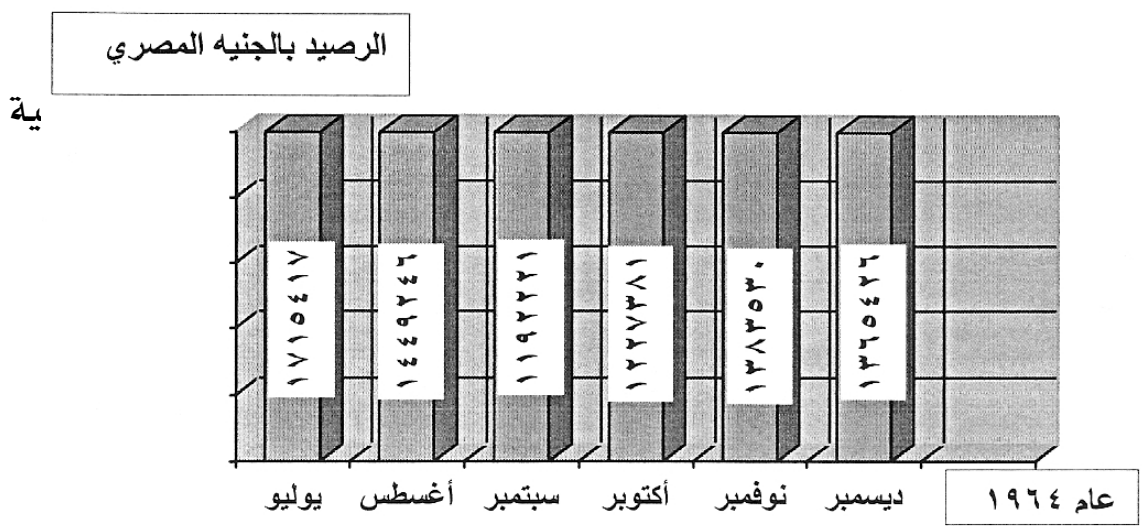


( رصيد الثركة لدى البنوك عام ع 1972 )

ومن هـذا البيـان يتضـح مدى متانة المـركز النقدى للشـركة لـدرجة أن هـذا الرصيد يهكن استفلاله فى الشركات الشقيقة التى تعانى من نقص السيولة ، أو الاشتراك مع شـركات مهاثلة فى تنفيذ الأعمال المسندة إليها ولا تجد إمكانات

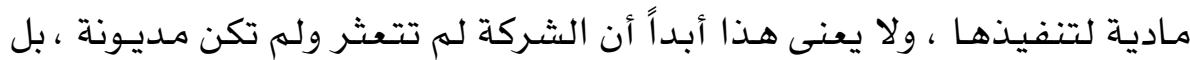

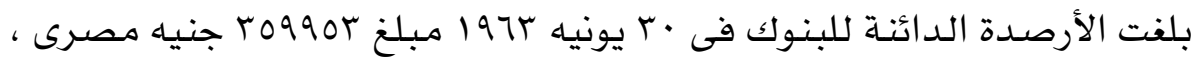
ولكن كان سبب هـذه المديونيـة قيـام الشـركة بـتدعيم أصولهها الثابتة بـإضـافة مشتريـات جـديدة بجـانب حـاجتهـا إلى تمـويل تكـاليف التوسع في عـمليات استصلاح الأراضى (00) .

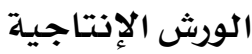

أولت الشـركة اهتهـامـا كبيـراً بالورش الإنتاجيـة الـرئيسيـة بـالإسكنـدريـة

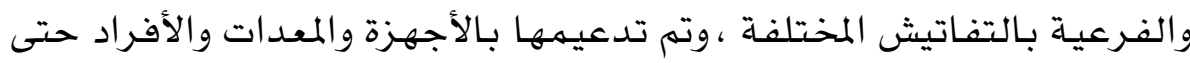

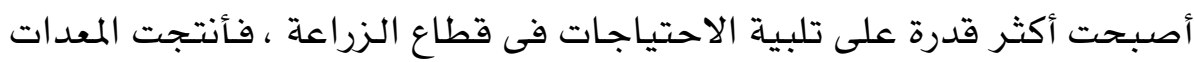

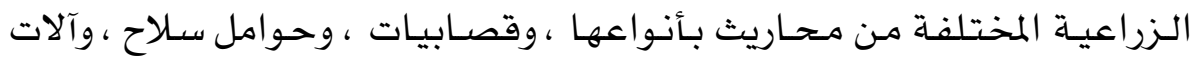

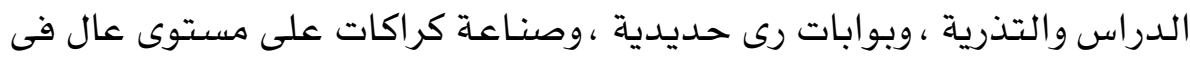

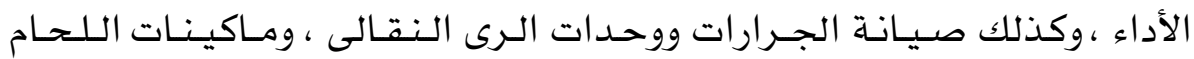

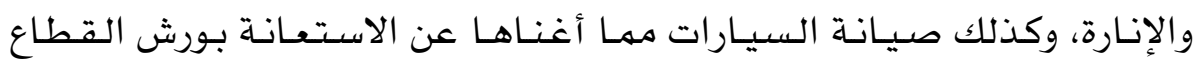

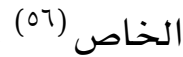
ولم يقتصر الأمر على قطاع الزراعة بل امتد الإنتاج ليشـمل قطاع التصنيع ،

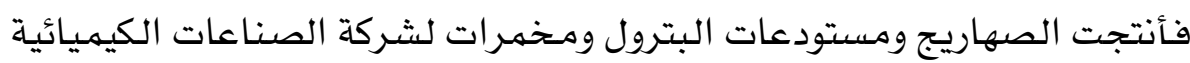
مثل شركة الحوامدية للكيهاويات ، وكذلك فى مجال الصناعات البحرية فأنتجت الونش العائم الذى تصل حمـولتها إلى •0 طن ، وهـو أكبر ونش عائم بنهر النيل

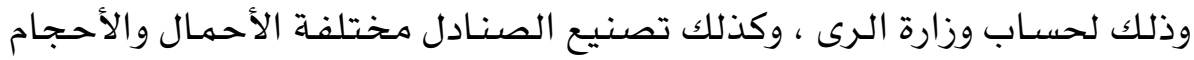

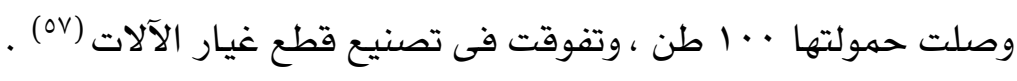


وكانت الشركة تضم أسطولاً كبيراً من الآلات والمعدات كالمحاريث والكراكات

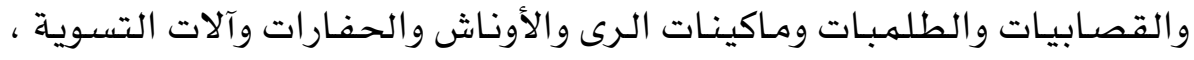

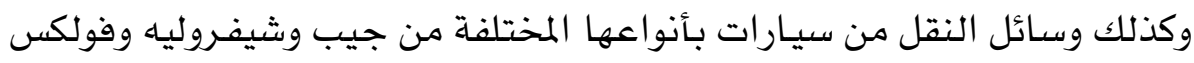

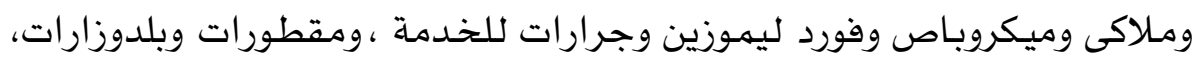

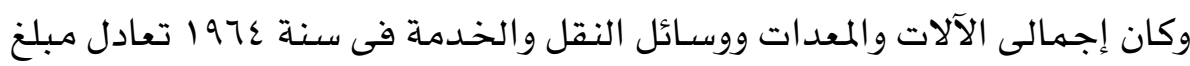

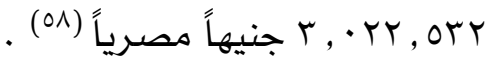
ومكنتها الوسائل العلميـة الحديثة من إنشاء خزانات ترابيـة بطريقة متطورة

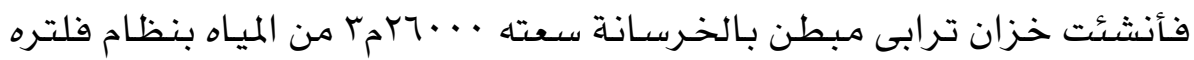
وشبكة أنابيب لتصريف المياه واستخدام الفواصل من الكاوتش لمنع تسرب بـت المياه ، وهله فواصل التمـدد والانكماش بهـواد كيهميائية خـاصـة لقطع تسـرب المياه ، ومقـاومـة عـوامل التعـريـة ، وقـامت كذلك بتتـفيذ الأعـهـال الحـديديـة الخـاصـة

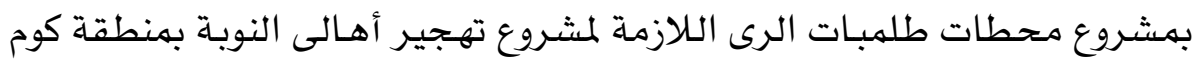

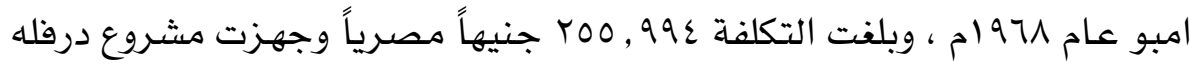

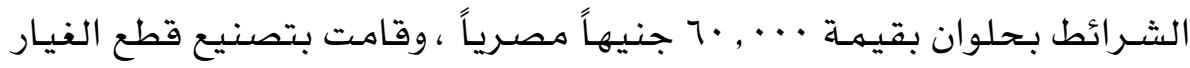

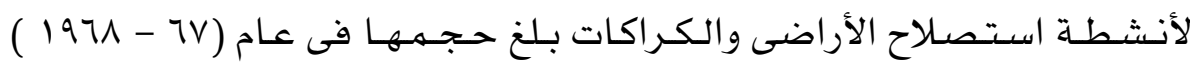
(09) r ro.

وكانت تقوم بعهل فريد من نوعاه حيث ترسل إلى الهيئات والمؤسسـات التى التى

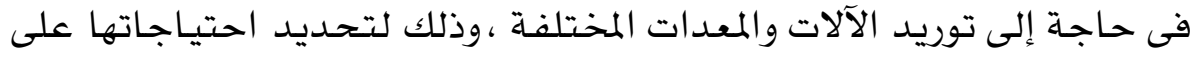
مدار العام ، لإمكان وضع خطة ثابتة للإنتاج وتقوم بإعداد دراسـة تفصيلية بهذا

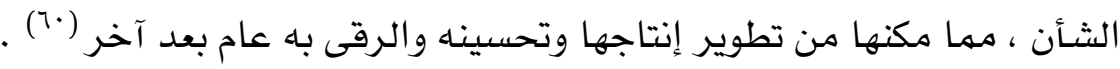
ومن العوامل التى ساعدت على شهرة الشـركة فى ميدان الصناعات المعدنية

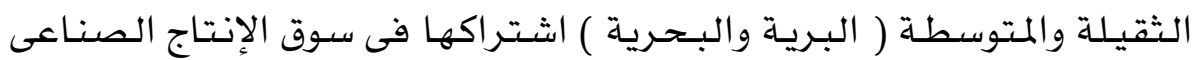
والزراعى فى موسم (09 - - • 197 ) حيث حصلت على عقود كثيرة وهـامـة منها بناء عدد ضخم من صهاريج البترول الكبيرة فى أنحاء القطر المصرى، وبناء عدد 
كبيـر من الصـنــادل وصـنـاعـة عـدد كبـيـر من الآلات الـزراعيـة كـالبـلـدوزرات والقصابيات والمنتجات المعدنية التى لاغنى لبلد نـاهض يسعى لتصنيع كافة

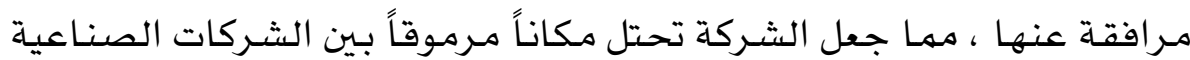
الكبرى فى مصر وخارجها( آ)، وحرصت الشركة على أن يكون لها قصب لهب السبق

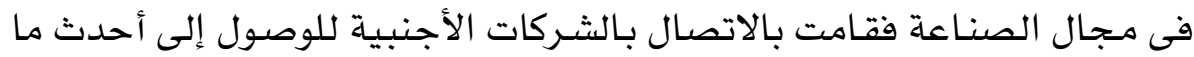

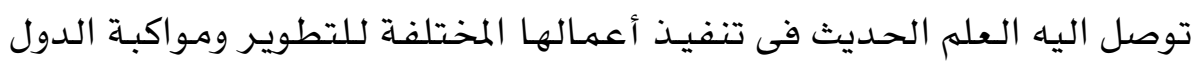

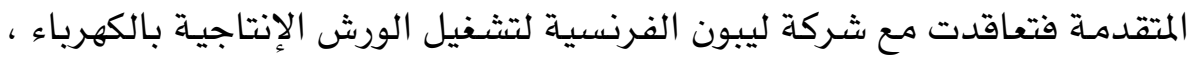

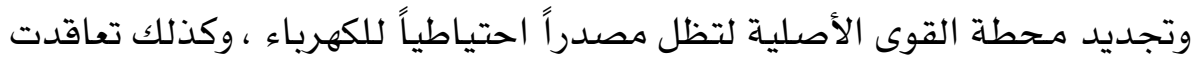

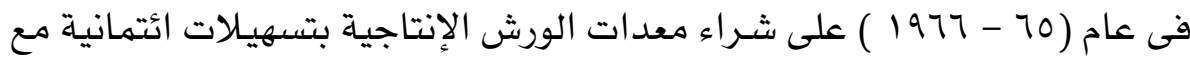
بولندا ورومانيا وألمـانيا الشـرقية بلفت قيمتها عن مخارط وماكينات نجارة ولف وثقاب وونش ووحدات توليد الكهرياء (·r لك . . $^{(7)}(1$ )

وكان أوج نشاط الشركة فى الستينيات وأوائل السبعينيات من القرى العشرين

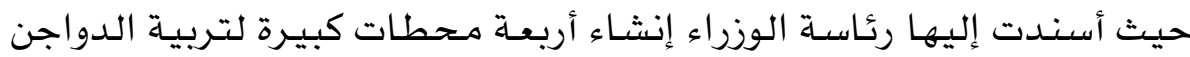

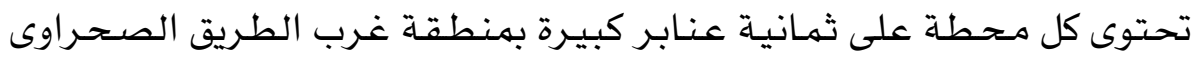

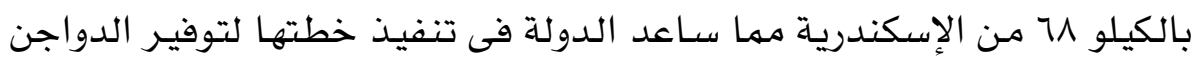
للمواطنين (Tr) بلتون

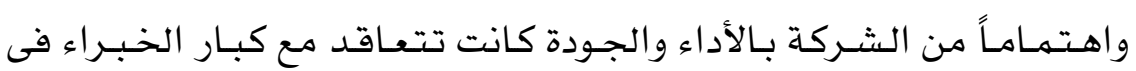

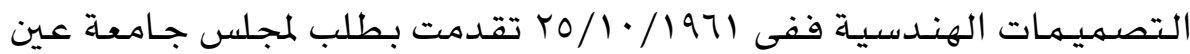

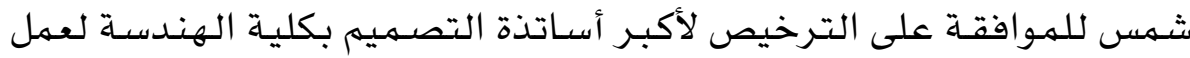

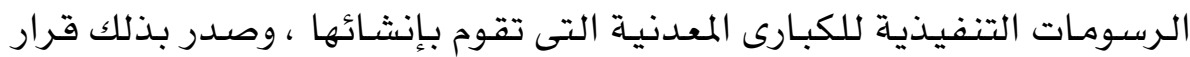

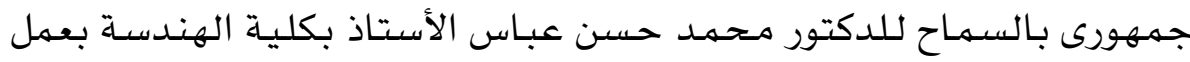

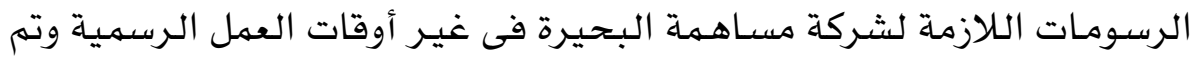




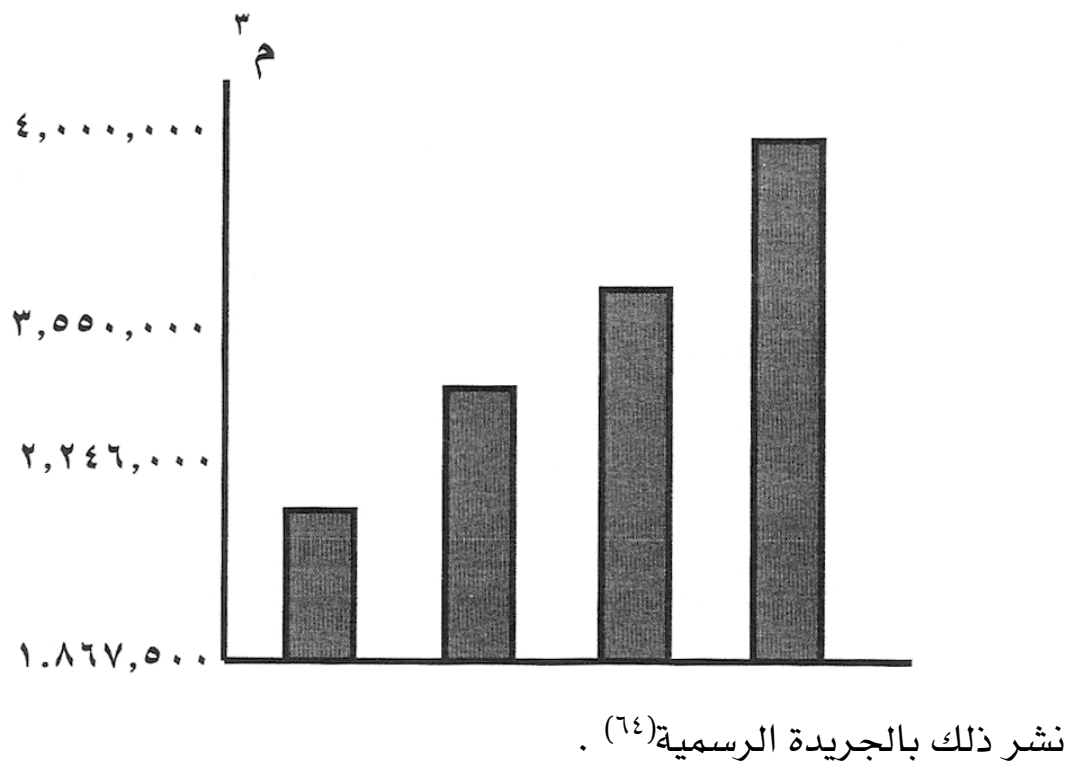

وتعاقدت الشـركة مع وزارة الرى المصرية لتطهير وتجريف ترعة المحمودية

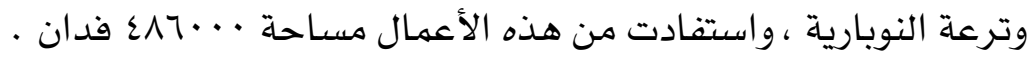
شكل ( 7 ( )

(عقد تجريف وتطهير ترعتى المحمـودية والنوبارية بين شـركة البحيرة ووزارة

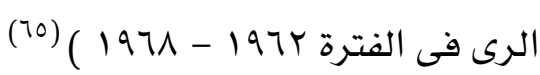
وهـذا الشكل يبيـن الحجمى الكبيـرللأعـمال التى قامت بها وحدة الكراكات بشـركة مسـاهمة البحيرة ، وكانت الشـركة تقوم باستبـدال الوحدات القديهة من

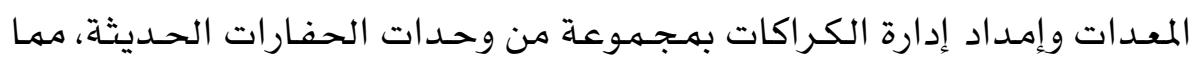

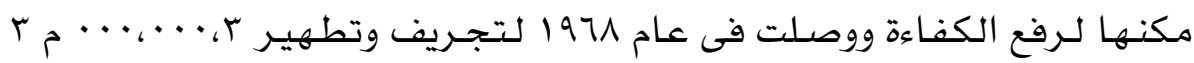


شركة مساهمة البحيرة ونشاطها الزراعى والصناعى فى مصر وخارجها (1111 - 19V0)

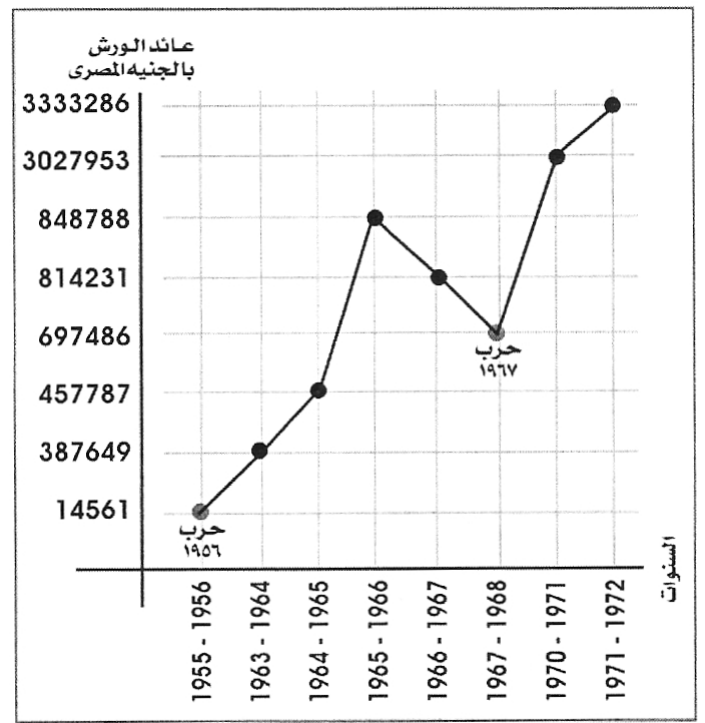

لترعتى المحمودية والنوباريـة ـ وهذا يدلل الكفاءة العالية التى وصلت إليها وحدة الكراكات بالشركة ولذلك كانت محل ثقة الحكومة التى كانت تتعاقد معها لفترات طويلة .

$$
\text { (V) شكل (1) }
$$

شكل يـوضح نشـاط الورش الإنتاجيـة لشـركة مسـاهــة البـحيرة فى الفترة

(77) $(19 V T-1900)$

من الشكل تبين زيادة نشاط الورش الإنتاجية زيادة كبيرة عام عن الذى يليه مها يؤكد على المقاولات الكبيرة والمثناريع الضخمة التى قامت بها الشركة وهذا

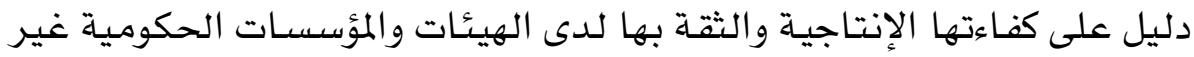
الحكوميـة ،ونـلاحظ مـن الشكل انـخفاض فى مـوسـهـين الأول (1900 - 1907 ) والثانى ( 1977 - 1977 ) و 1971 - 1971 ) ) وذلك للظروف التوف التى كانت تمـر بها

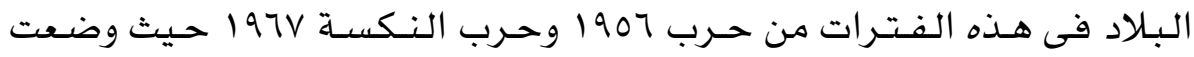

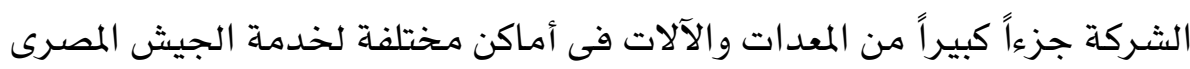

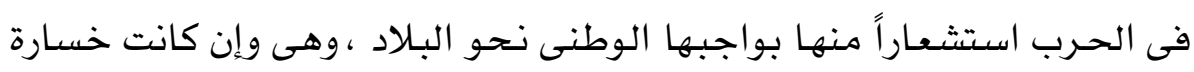

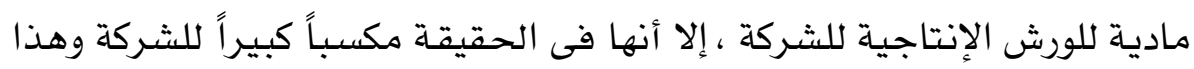


يدل على الانتماء الحقيقى والوطنيـة الصـادقة ، ولكن الورش الإنتاجيـة حققت

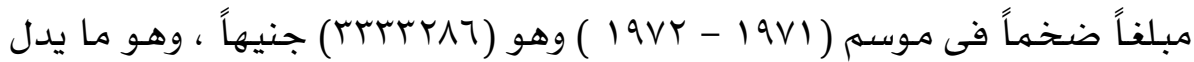
على الأرباح الكبيرة التى جنتها الشركة من وراء الورش الإنتاجية .

نشاط الشركة خارج مصر

أصبـحت شـركة مسـاهـهـة البـحيـرة من أشهر الشـركات فى مصـر فى مجـال

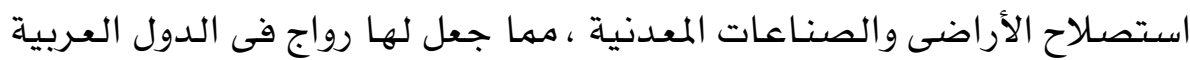
الشقيقة ، فقامت الشركة بهشروع تاورغاء وهو أحد المشاريع الكبيرة بالجمهورية

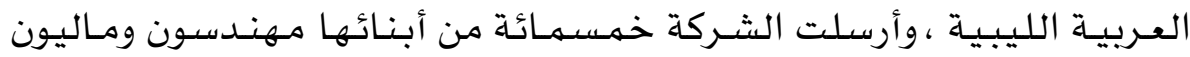

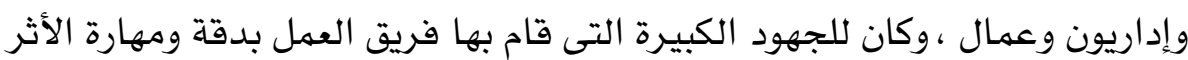
الكبير فى نجاح المشروع والقضاء على منافسة الشركات الأجنبية الموجودة بليبيا

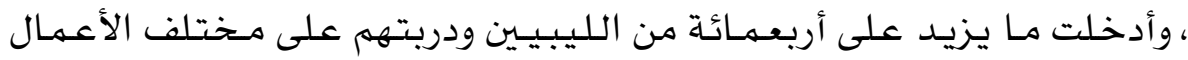

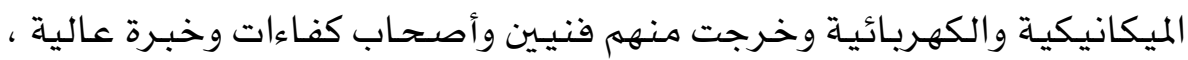

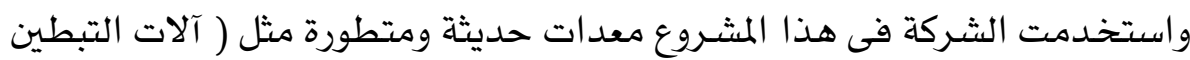
المنزلقة ( Slip Form وذلك لتبطين قنوات الرى المكشئوفة وتعتبر هـذه أول مرة تستخدم فيها مثل هـذه الآلات على نطاق واسـع فى شـــال إفريقيا ، وتم تبطين

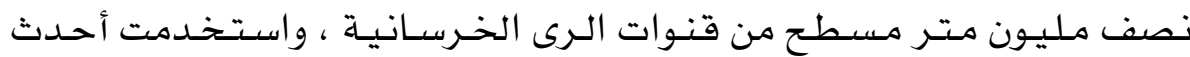

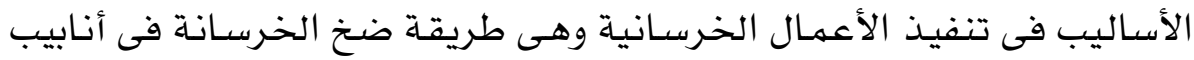

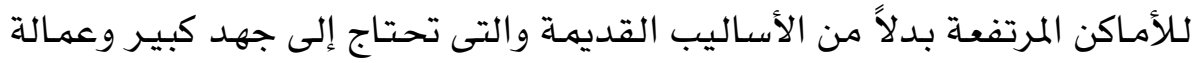

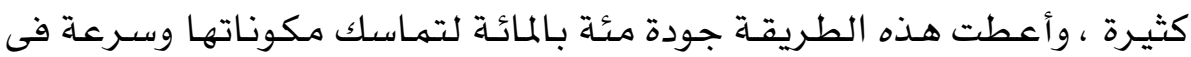

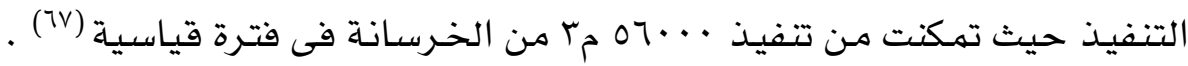

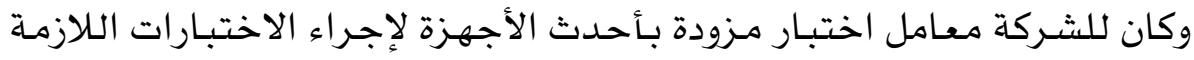

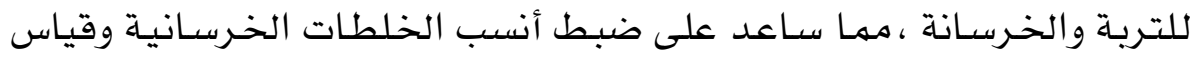
الجهد اللازم للترية وأعمال الضغط ، كما استخدمت معدات ( موتور سكريبر )

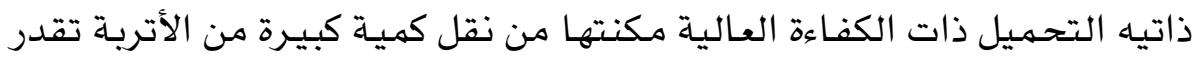


بحوالى ه, ب مليون متر مكعب لمسـافة ... ام وقامت الشـركة لأول مـرة بتنفيذ

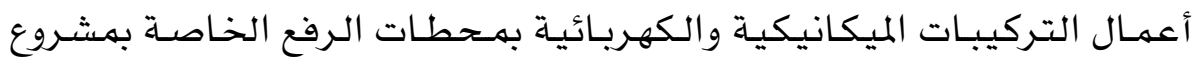

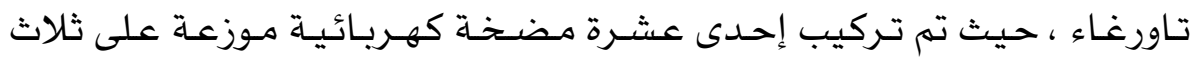

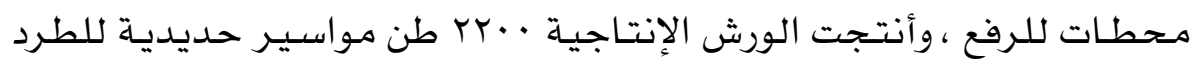

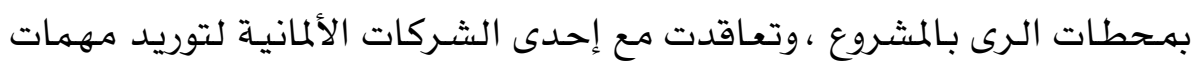

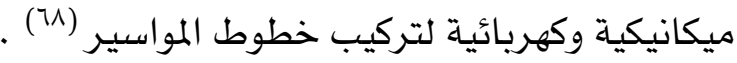
ومن العوامل التى سـاعدت على ربط مواقع العمل المختلفـة وسـرعة تدارك أى

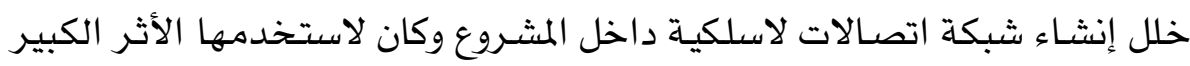

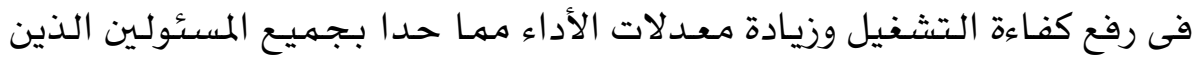

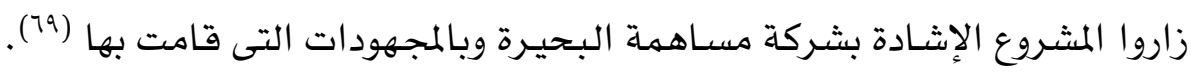

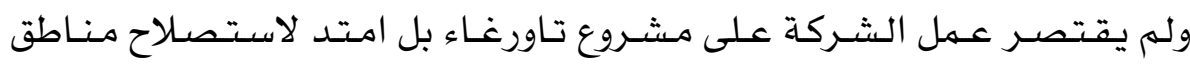

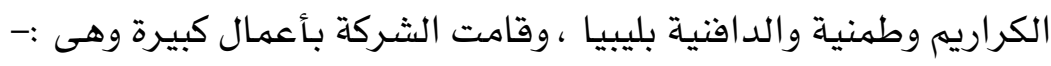

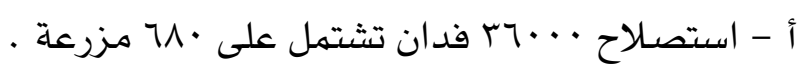

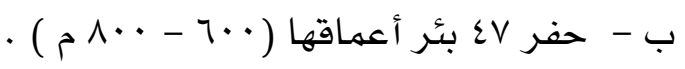

$$
\begin{aligned}
& \text { ج - إنشاء مساكن لعدد } 7 \text { م مزارع • } \\
& \text { دـ - إنشاء قرية مركزية . }
\end{aligned}
$$

هـ - إنثاء طرق ( درجة أولى •0 كم - درجة ثانية 0, ب ا كم - طرق خدمية

و - استصلاح منطقة بئر الغنم ومساحتها ل.. 10 فدان وتشمل:

$$
\text { - }
$$

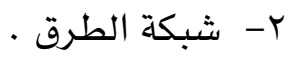

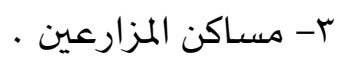

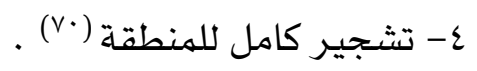


وتعـاقدت الشـركة مع جهـهوريـة السـودان بعقـود لتصنيع طلهـبات أعهماق

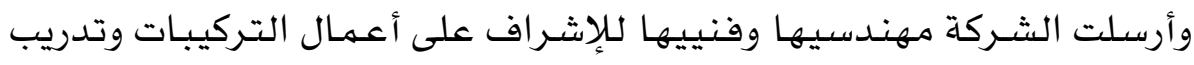

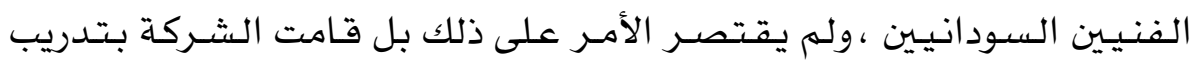

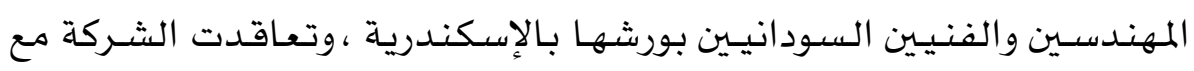

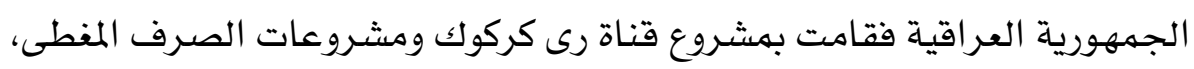

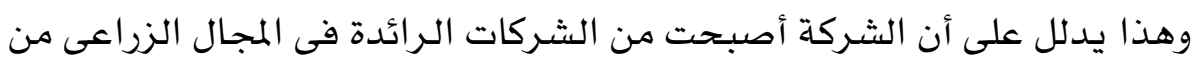

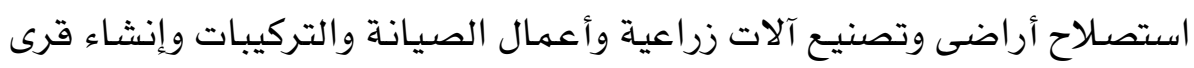

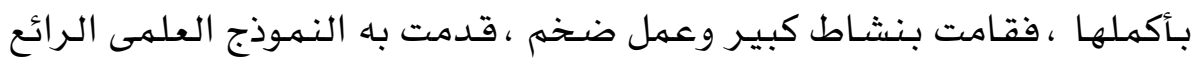


والتجرية الناجحة ، واستصلحت بـآلاتها ومعداتها مسـاحات كبيرة من الأراضى

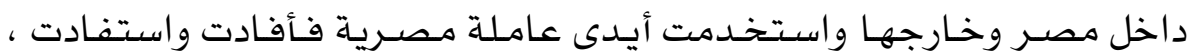

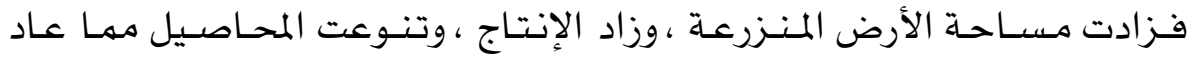
بالفائدة الكبيرة على مصر اقتصاديا واجتهاعيا (V)

الخـاتمهة

من خلال العرض السابق يتضح بجـلاء أن شركة مساهـمة البحيرة كانت تقوم

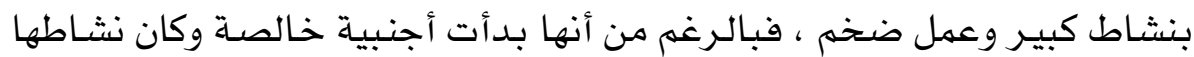

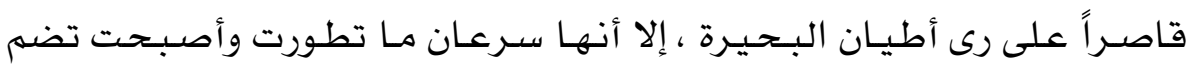

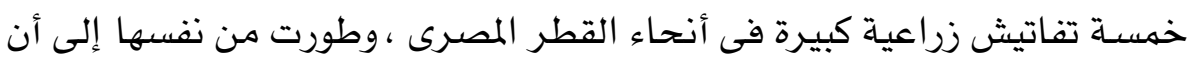

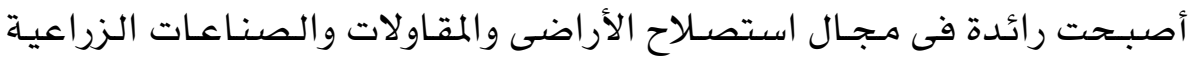

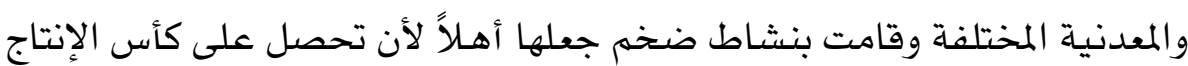

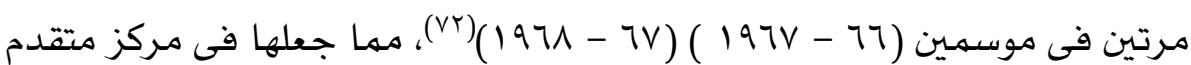

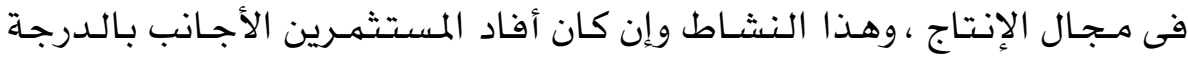

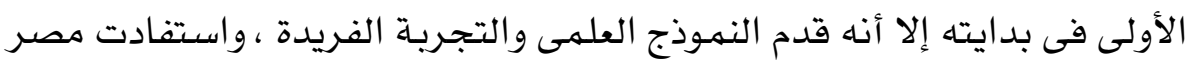
من استصلاح مسـاحات كبيرة من الأراضى البور واستخدام الأسـاليب العلهية

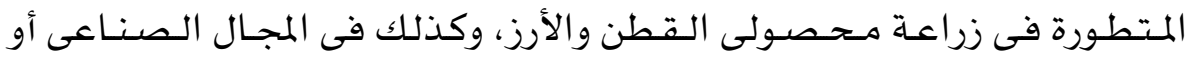
استخدمت فى ذلك كله أيدى عاملة مصرية فأفادت واستفادت ،وما أن بزخ فجر الستينيات من القرن العشرين إلا وأصبحت الشـركة مصرية خالصة فهى بدأت

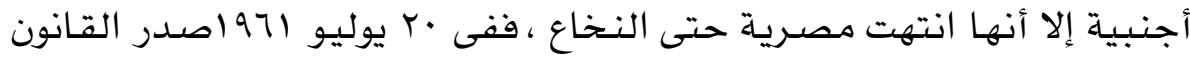

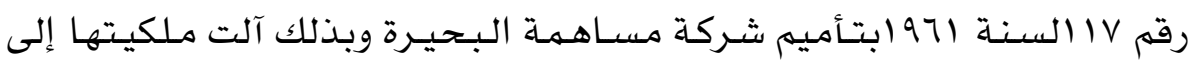

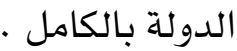

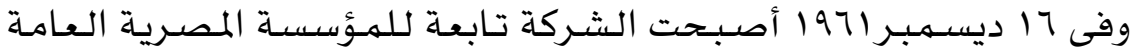

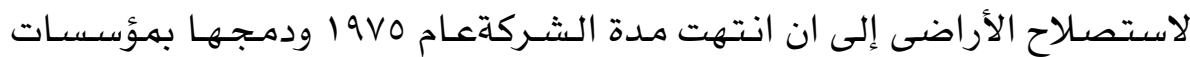


ورغم أن الشركة قابلت فى مسارها الطويل حملات مهنهجه لهدمها وتشويه

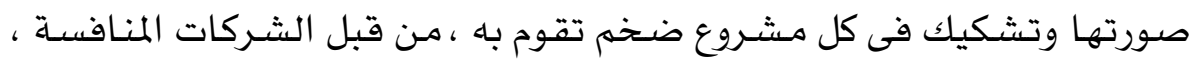

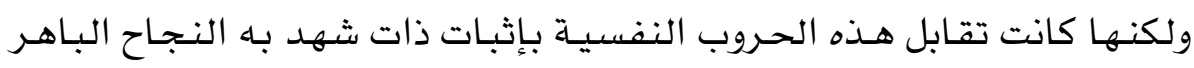

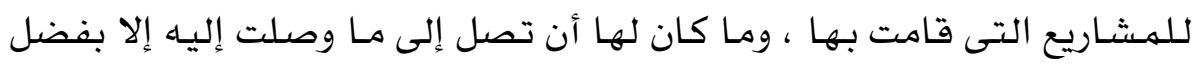

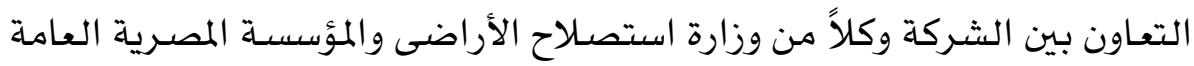

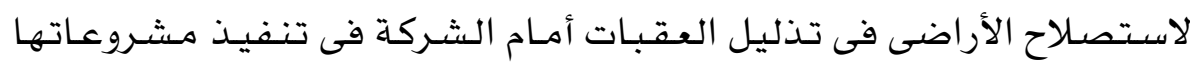

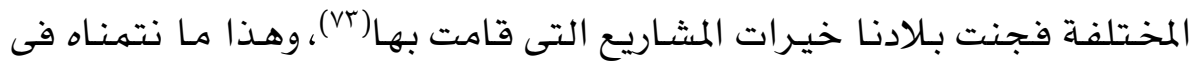

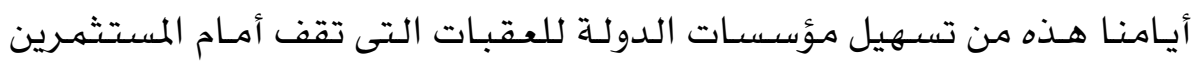

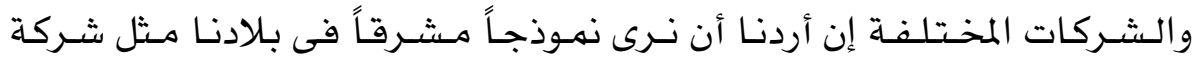

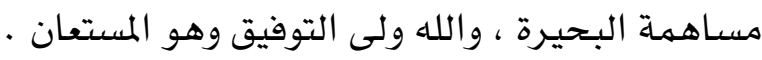




\section{الهوامش}

(1) حسين خلاف : التجديد فى الاقتصاد المصرى، دار إحياء الكتب العربية ، الطبعة الأولى ،

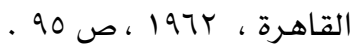

(r) أحمد أحمد الحته : تاريخ مصر الاقتصادى فى ق 19 ، ، النهضة المصرية ، الطبعة الثالثة ،

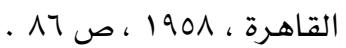

(3) Crouchley The investment offoreign Capitalin Egyptian Companies - and public dept press bulaq 1938, P.44

(4) - Ibid . P.105

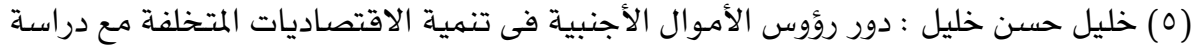

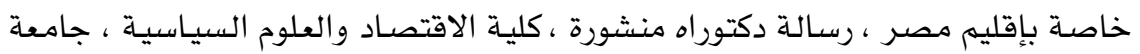

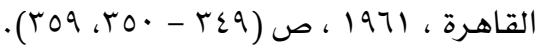

(6) Crouchley . op. Cit P.110

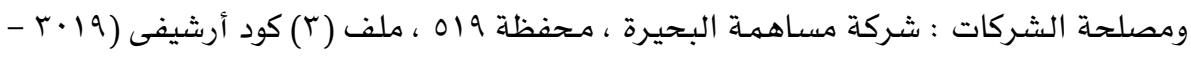

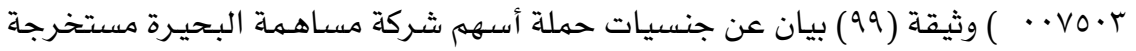

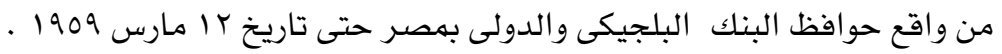

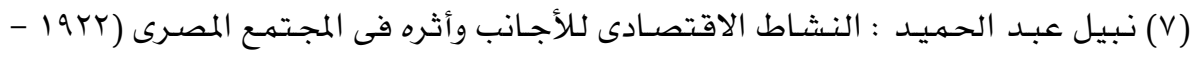

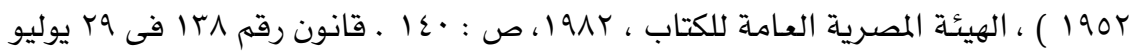

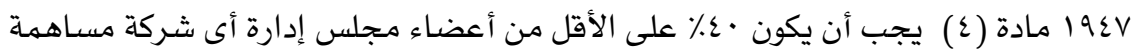

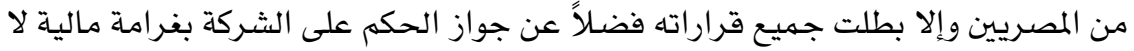

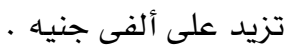

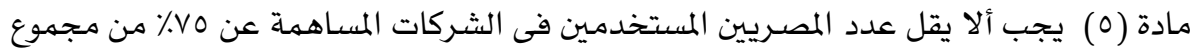

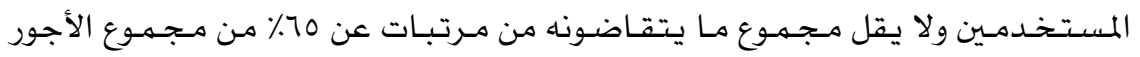

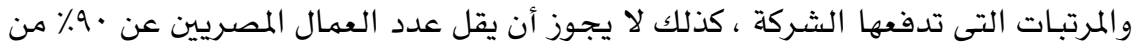

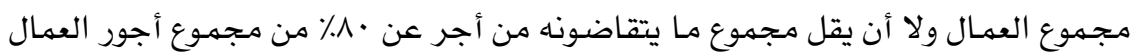

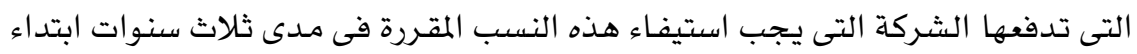

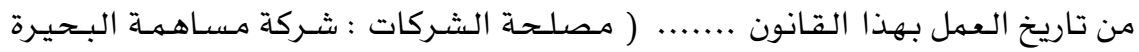

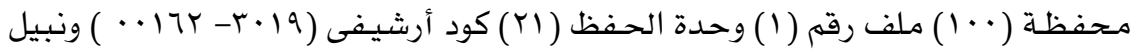

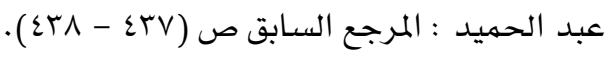

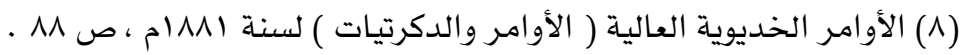




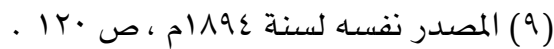

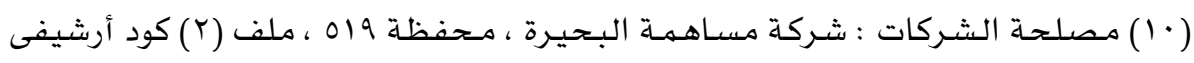

$$
\cdot(\cdots V 0 \cdot r-r \cdot 19)
$$

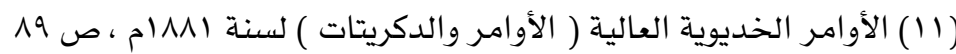

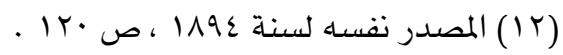

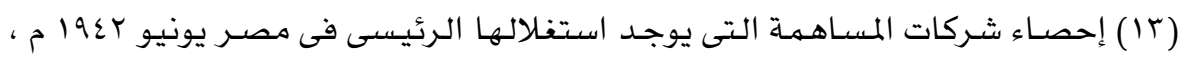

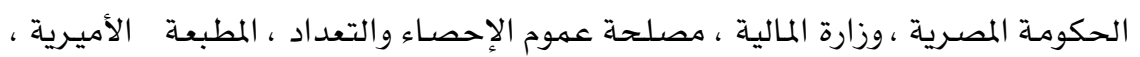

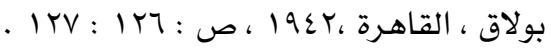

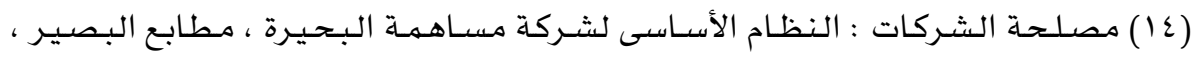

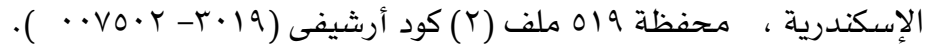

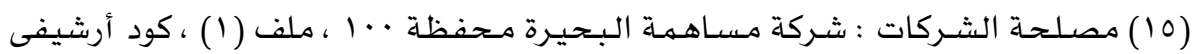

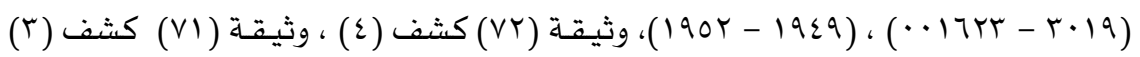

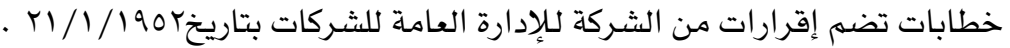

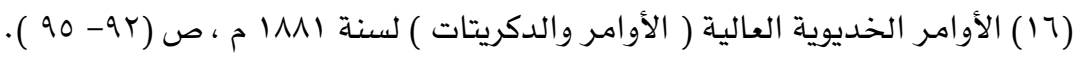

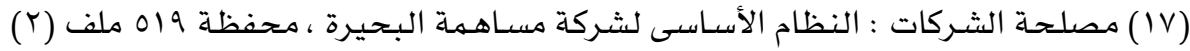

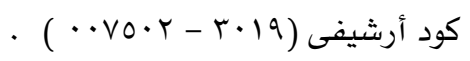

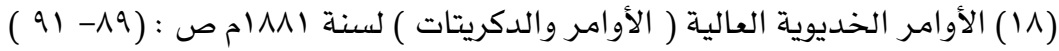

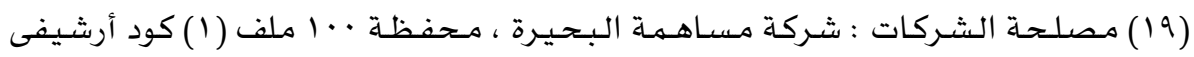

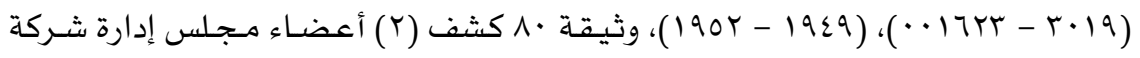

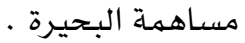

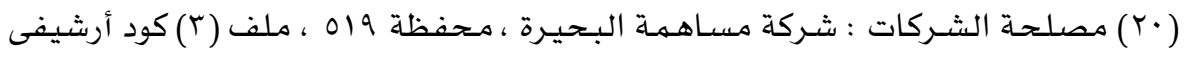

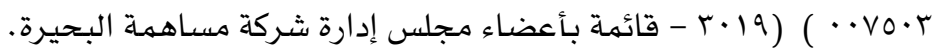

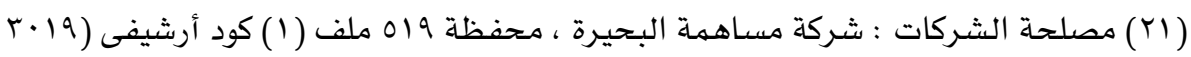

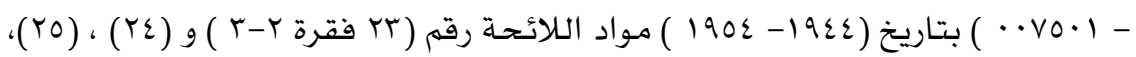

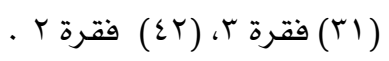

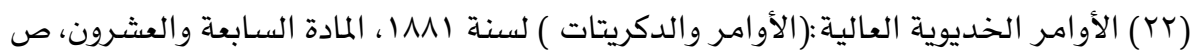

$(1.1-99)$

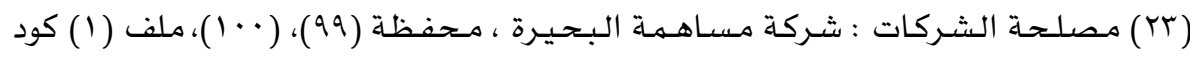

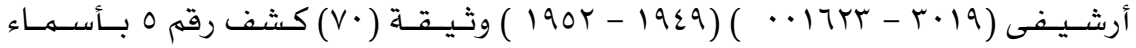

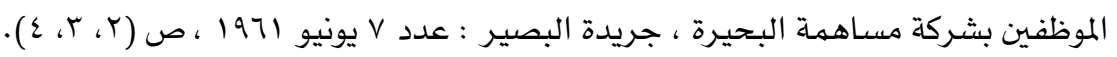

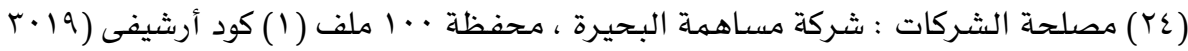

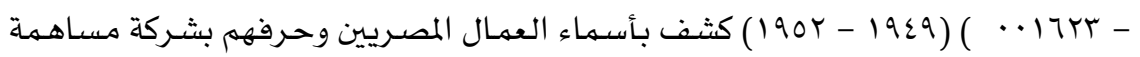




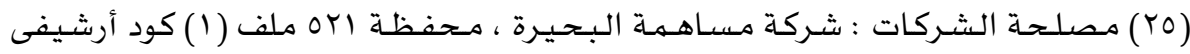

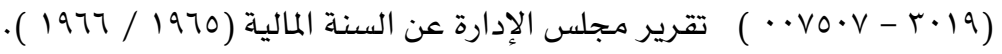

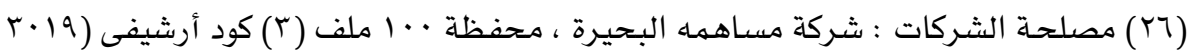

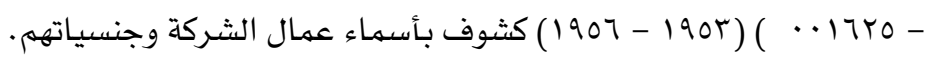
مصلحة الشـركات: شـركة مساهمـة البحيرة ، محفظة (YV) -

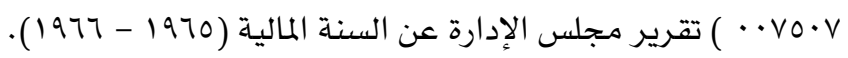

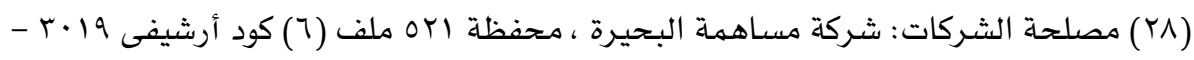

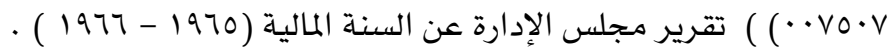

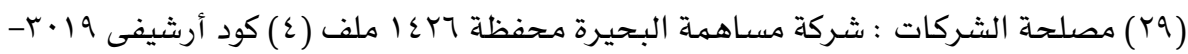

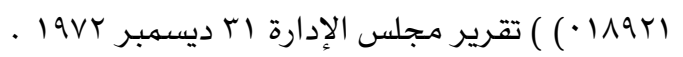
(30) No . 15321 .P (1 2 ) Journal Commerce et Dela marine , 8 Juin 1961

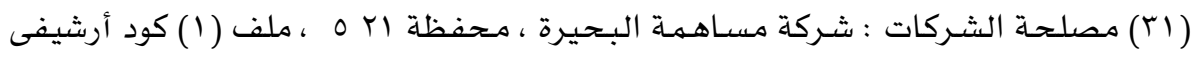

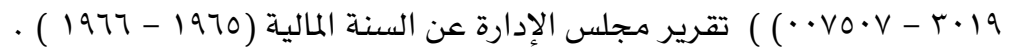

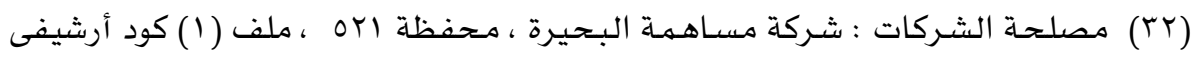

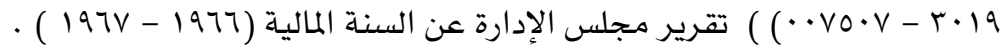

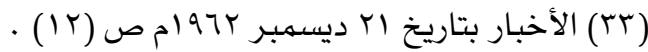

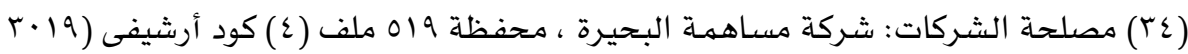

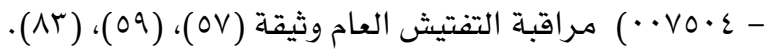

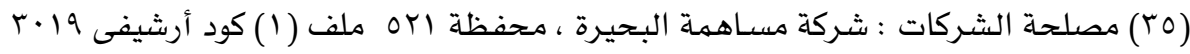

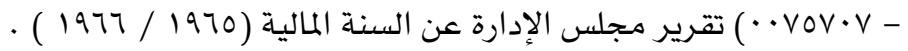

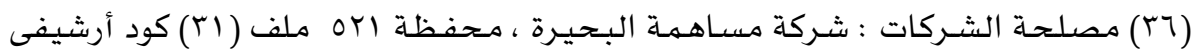

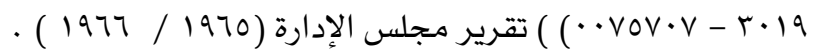
مصلحة الشركات: شركة مسـاهمة البحيرة ، محفظة (rV)

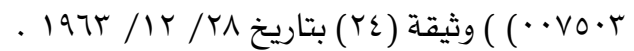

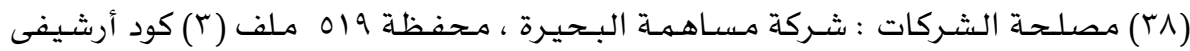

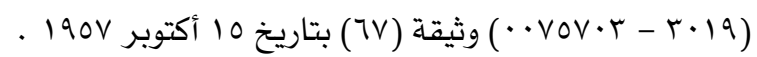

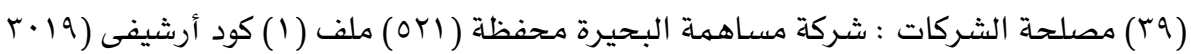
/ TV VOV·V -

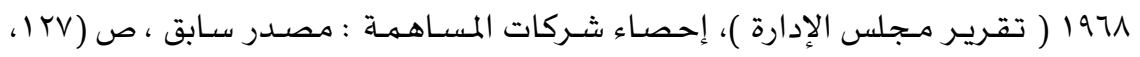

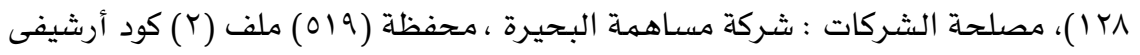




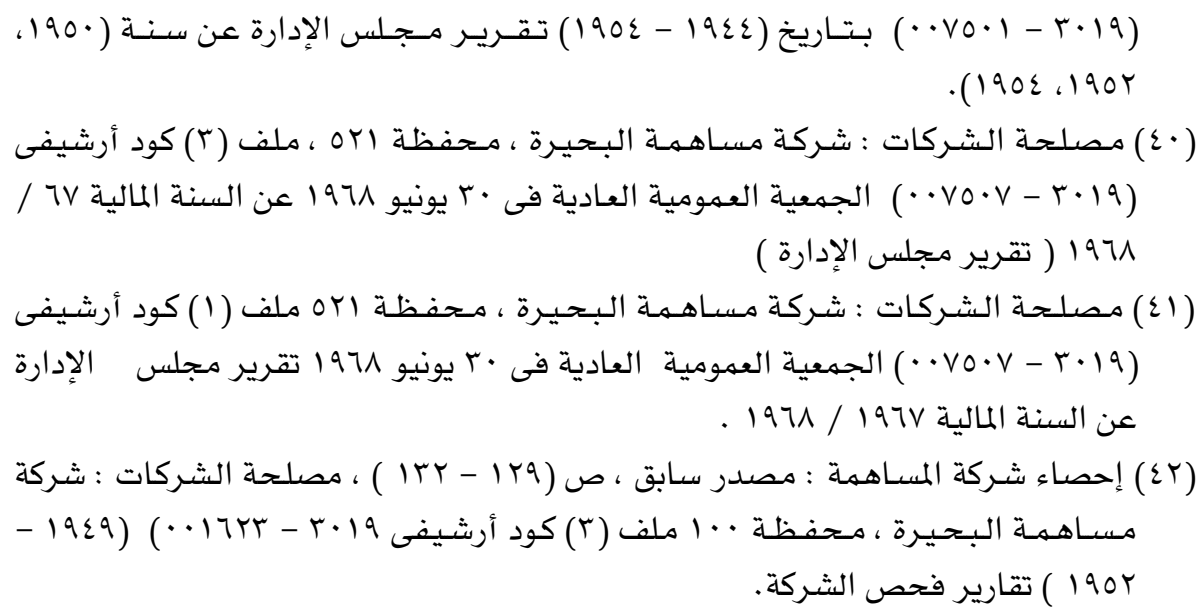

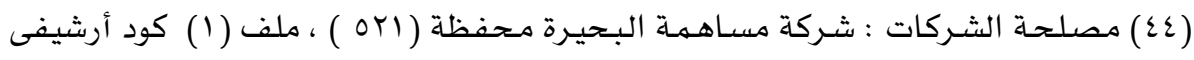

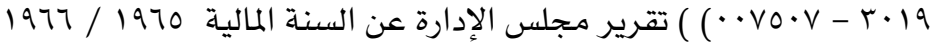

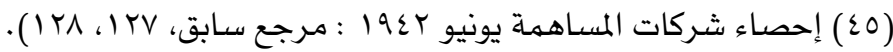

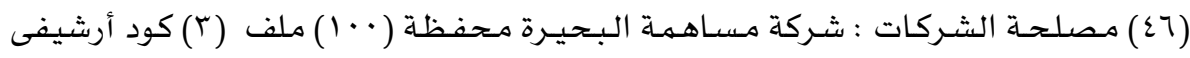

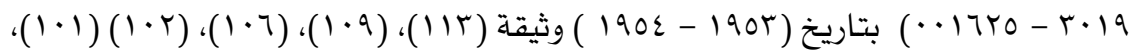

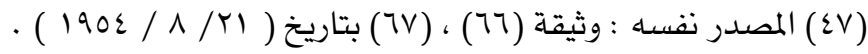

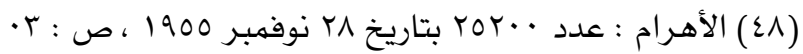

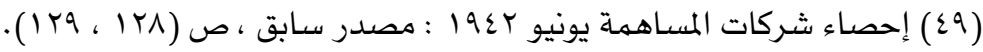
(0)

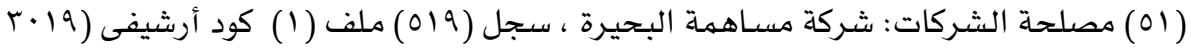

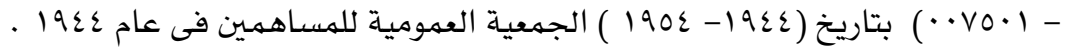

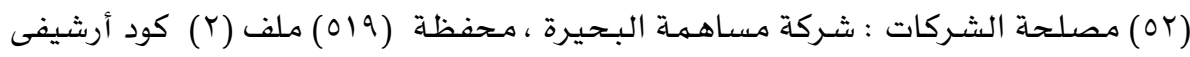

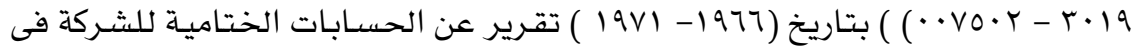




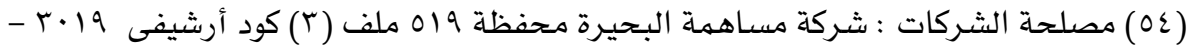

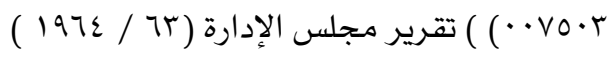

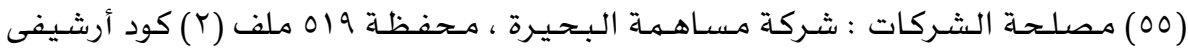

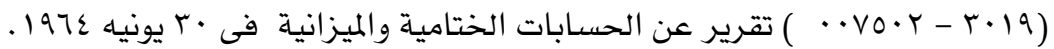

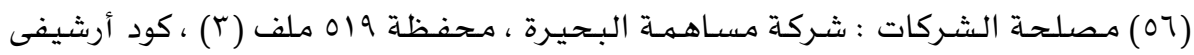

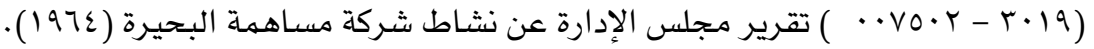

(OV)

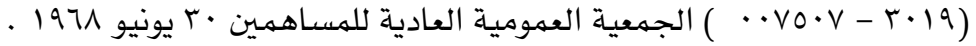

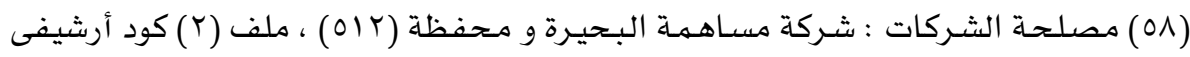
$(\cdots V 0 . r-r \cdot 19)$

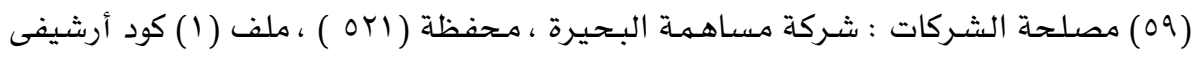

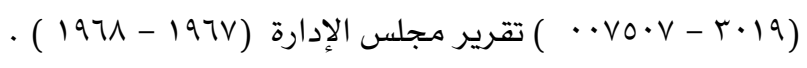

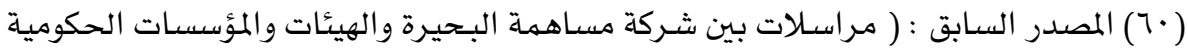

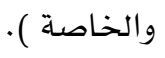

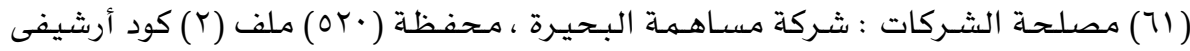

$$
\text { . }
$$

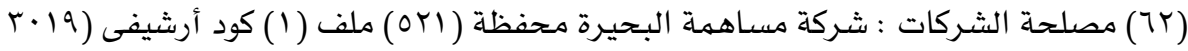

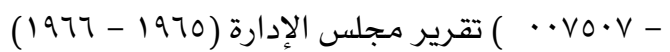

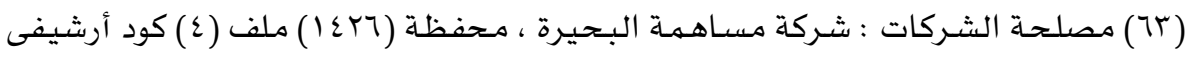

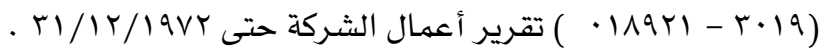

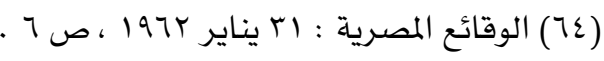

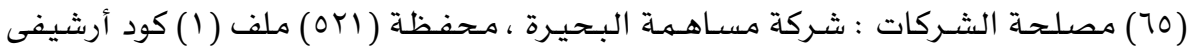

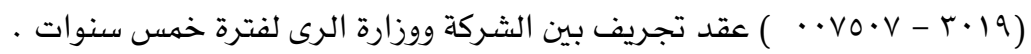

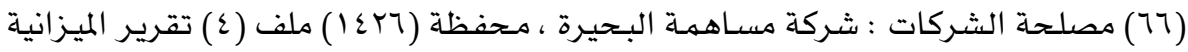

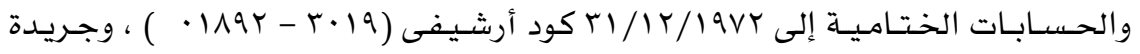

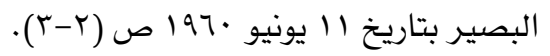

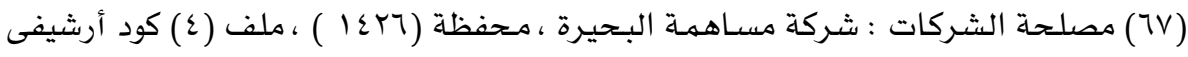

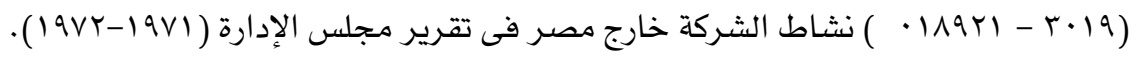


. مصدما (VI)

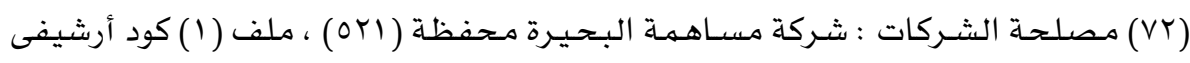

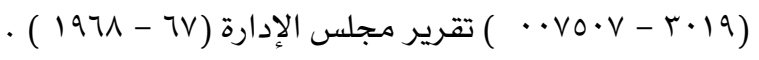

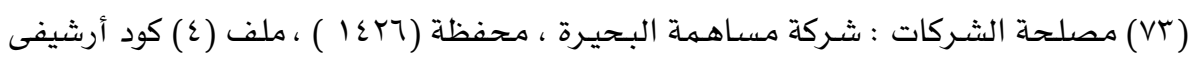

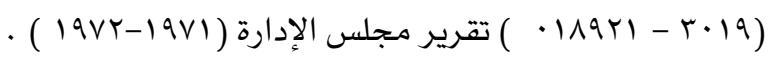

